\title{
ANÁLISIS REGULATORIO DE LOS PROCESOS DE SELECCIÓN DE OPERADORES PRIVADOS DEL SERVICIO PÚBLICO DE TELEVISIÓN, EN TORNO A LA LIBRE CONCURRENCIA, DADA LA EXISTENCIA DE DOS OPERADORES INCUMBENTES.
}

\section{RESUMEN}

La regulación del servicio público de televisión prestado a través de operadores privados surgió en el año 1986, materializándose la primera y única selección de estos concesionarios en el año 1987, contratos que involucran la prestación de un servicio público y la asignación de frecuencias del espectro electromagnético, en aplicación de la reglamentación del sector en general de las tecnologías de la información y las comunicaciones, así como las disposiciones generales inherentes a la selección del contratista, pero que en todo caso están gobernados por los principios de la contratación pública siendo de especial relevancia el relativo a la libre competencia reflejada en la libre concurrencia y la existencia de un marco juridico que lo haga posible. Siendo relevante analizar la evolución en la regulación, la desconcentración de la actividad intervencionista en diferentes autoridades administrativas con claras competencias, la alineación con las políticas de Unión Internacional de Telecomunicaciones -UIT- de la cual Colombia es miembro.

\section{INTRODUCCIÓN}

La garantía de la libre competencia y participación de nuevos interesados, diferentes a los concesionarios incumbentes, desde el punto de vista regulatorio nos lleva a generar un análisis de aspectos trascendentales tales como la inversión extranjera, el régimen de inhabilidades específicas para este tipo de procesos, las exigencias del Registro Único de Operadores, los pactos contractuales existentes, los requisitos específicos para la asignación del espectro electromagnético, pronunciamientos únicos, específicos y dirigidos a cada uno de los trámites fallidos de procesos de selección de este orden por parte de organismos de control y del Consejo de Estado, aunado al análisis de los demás componentes de la reglamentación que sirven de sustento.

No podemos abstraernos de una realidad consistente en que a la fecha los concesionarios incumbentes están próximos a finalizar la ejecución de sus actos de prórroga, sin que haya sido posible adjudicar nuevas concesiones de operadores privados del servicio, por razones imputables básicamente a la inexistencia de garantías que posibilitaran la libre competencia y entrada de nuevos competidores al mercado, debiéndose validar si esas barreras de entrada están dadas o no en el referido marco regulatorio.

No se cuenta con antecedentes escritos sobre el análisis a nivel de doctrina, académica o investigación frente al tema específico de investigación que nos ocupa, y que contribuya a validar el que la libre competencia esté garantizada al permitirse la entrada al mercado de operadores privados de nuevos competidores diferentes a los incumbentes; de ahí que se involucró como metodología la investigación básica, soportada en la identificación y análisis de los elementos legales, jurisprudenciales y doctrinarios que sustentan el tema propuesto dejando claramente definido el marco legal, los conceptos legales técnicos y financieros y su alcance en la aplicación 
de los mismos en la práctica del desarrollo de un proceso de selección de concesionarios públicos de operación privada de televisión abierta; determinando los requisitos específicos del procedimiento, sus connotaciones, repercusiones y aplicabilidad en la práctica jurídica.

Dado que se cuenta con una evolución normativa, es importante validar que esta sea suficiente y brinde protección y garantía a la entrada de nuevos competidores a ese mercado que se ha negado la posibilidad durante casi dieciséis años; o si por el contrario existen vacíos regulatorios o barreras que impidan la materialización de esa competencia orientada a garantizar la entrada de nuevos jugadores en el manejo de la pauta publicitaria.

\section{Marco jurídico de la Licitación Pública del Servicio Público de Televisión.}

El marco regulatorio del proceso de selección de los operadores privados del servicio público de televisión está reglamentado por normas de carácter especial (Llaneza, 2002, p.56-59), en las que se determina el procedimiento durante la etapa de planeación, desarrollo del proceso de selección, su contratación, ejecución y liquidación, nos referimos a las disposiciones contempladas en las Leyes 182 (Congreso de la República, 1995, p.1-33) ${ }^{1}, \quad 335$ (Congreso,1996,p.1-33) $)^{2}, 506$ (Congreso,1999, p. 1-2) ${ }^{3}, 680$ (Congreso, 2001) ${ }^{4}$; el cual ha sido objeto de modificación y actualización durante los últimos años; modificaciones materializadas principalmente en las Leyes 1341(Congreso, 2009) ${ }^{5}$, 1507(Congreso, 2012) ${ }^{6}$, y algunos Decretos reglamentarios de esta última, obteniéndose una mayor compilación normativa frente a la reglamentación del servicio público de televisión, y específicamente para el caso que nos ocupa, en lo referente al servicio de televisión abierta con cubrimiento nacional brindado por operadores privados.

Igualmente se rige por el régimen general de contratación pública consagrado en las Leyes 80(Tapias Perdigon, 2000, p.1-180) ${ }^{7}, 1150$ (Congreso,2007,p.1-) ${ }^{8}, 1474$ (Congreso 2011, p 1-77), Decretos Ley 019 (Presidencia de la República, 2012, p.78-85) ${ }^{10}$ y de unificación 1082 (Dávila Vinueza \& Neyva Morales, 2015, p. 1-127) ${ }^{11}$, y demás normas que lo modifiquen, en cuanto le son aplicables las disposiciones referentes a los principios generales de la contratación pública (Castro Cuenca, Garcia López, \& Martinez Vargas, 2010,p. 123-161), el mecanismo de selección de contratista aplicable, reglas inherentes a la adjudicación, perfeccionamiento, legalización, ejecución, control y vigilancia contractual y demás aspectos relacionados.

1 Diario Oficial No. 41.681, reglamenta el servicio de televisión y se formulan políticas para su desarrollo, se democratiza el acceso a éste, se conforma la Comisión Nacional de Televisión, se promueven la industria y actividades de televisión, se establecen normas para contratación de los servicios, se reestructuran entidades del sector y se dictan otras disposiciones en materia de telecomunicaciones. Bogotá, 1995.

2 Diario Oficial No. 41.681, modifica parcialmente la Ley 14 de 1991 y la Ley 182 de 1995, se crea la televisión privada en Colombia y se dictan otras disposiciones. Bogotá, 1996.

3 Diario oficial 43.652, modifica el artículo 58 de la Ley 182 de 1995. Bogotá, 1999.

4 Diario Oficial 44.516, reforman las Leyes 14 de 1991, 182 de 1995, 335 de 1996 y se dictan otras disposiciones en materia de Televisión, Bogotá, 2001.

5 Diario Oficial 47426, definen principios y conceptos sobre la sociedad de la información y la organización de las Tecnologías de la Información y las Comunicaciones -TIC-, se crea la Agencia Nacional de Espectro y se dictan otras disposiciones. Bogotá, 2009.

6 Diario Oficial 48308. establece la distribución de competencias entre las entidades del Estado en materia de televisión y se dictan otras disposiciones. Bogotá, 2012

7 Diario Oficial 41094,Estatuto General de Contratación de la Administración Pública. Bogotá, 1993.

8 Diario Oficial 46691, medidas para la eficiencia y la transparencia en la Ley 80 de 1993 y disposiciones sobre contratación con Recursos Públicos. Bogotá, 2007.

9 Diario Oficial 48128, mecanismos de prevención, investigación y sanción de actos de corrupción y la efectividad del control de la gestión pública. . Bogotá, 2011.

10 Diario Oficial 48308, normas para suprimir o reformar regulaciones, procedimientos y trámites innecesarios existentes en la Administración Pública. Bogotá, 2012.

11 Diario Oficial 49523,reglamentario del sector administrativo de planeación nacional. Bogotá, 2015. 
Por ello procedemos a generar el análisis y conocimiento del marco regulatorio desde diferentes perspectivas, a saber el Servicio Público de Televisión, el proceso de selección de los contratistas, la concesión de operadores privados, la libre competencia, el espectro electromagnético y su asignación, atribución y adjudicación para el servicio en concreto (Dallos Jabbour, 2014, p.13-45), y en general el mercado de operadores y los factores de competencia frente a ese mercado.

\subsection{Normas, disposiciones y conceptos Constitucionales.}

El referido componente normativo procedemos a esbozarlo en una forma detallada e ilustrada atendiendo el nivel jerárquico de las normas, las competencias inherentes a la preparación de los procesos de selección de contratistas, la celebración y ejecución de los contratos que pacta el Estado para cumplir con el objeto especifico referido a la prestación del servicio público de televisión abierta con cubrimiento nacional a través de operadores privados, todo ello en torno al hecho generador del presente trabajo de investigación, esto es analizar si ¿La licitación Pública como proceso de selección para adjudicar las concesiones del servicio público de televisión abierta de operación nacional y del espectro electromagnético a los operadores privados; vulnera el principio de libre competencia?, principio que igualmente cuenta con reglamentación jerárquica que procedemos a referirla en su aplicación al tema en concreto.

La sociedad de las Tecnologías de la Información y las Comunicaciones a nivel mundial viene evolucionando y Colombia no ha sido la excepción a esa dinámica ni al desarrollo que ello genera; es así como podemos evidenciar amplios avances en proyectos de telecomunicaciones sociales, internet en banda ancha, aplicaciones, comunicaciones móviles, tecnologías de última generación, radio, y televisión entre otros.

El Espectro electromagnético y el servicio público de televisión, como bien y servicio inherentes a la función social del Estado, constitucionalmente a efecto de asegurarse de que su uso y prestación sean coherentes con ese objetivo se encuentran protegidos en cuanto la carta dispone que la Ley será la que determine las autoridades para velar por el cumplimiento de las disposiciones referidas a garantizar la libre competencia; encomendando esa tutela y custodia a varias autoridades administrativas de conformidad con la Ley. La Libre competencia referida a la prestación del servicio y uso del Espectro Electromagnético ha contado con tratamiento no solo constitucional y legal sino jurisprudencial, que sirven de referente para conocer su evolución. (González López, 2010, p 16-122)

\section{a. Concepto Constitucional del Espectro Electromagnético.}

Nuestra Constitución Nacional, en su artículo 75 señala:

El espectro electromagnético es un bien público inenajenable e imprescriptible sujeto a la gestión y control del Estado. Se garantiza la igualdad de oportunidades en el acceso a su uso en los términos que fije la Ley.

Para garantizar el pluralismo informativo y la competencia, el Estado intervendrá por mandato de la Ley para evitar las prácticas monopolísticas en el uso del espectro electromagnético (Asamblea Nacional Constituyente, 1991, p.30). 
Adicionalmente, la Constitución Nacional en sus artículos 101 y 102, incorporados en su Título III, (Asamblea, 1991, p.39) establecen que el espectro electromagnético forma parte del territorio colombiano, y que tanto éste como los bienes públicos que lo conforman, pertenecen a la Nación.

Elementos de raigambre constitucional, que han sido desde la perspectiva constitucional y legal, objeto de tratamiento, en diferentes pronunciamientos de la Honorable Corte Constitucional $^{12}$, acudiremos a mencionar lo expuesto en la sentencia C- 570, en la que se ilustra de conformidad con el concepto constitucional, que:

El espectro electromagnético ha sido definido como una franja de espacio alrededor de la tierra a través de la cual se desplazan las ondas radioeléctricas que portan diversos mensajes sonoros o visuales, radicando su importancia en ser un bien con aptitud para transportar información e imágenes a corta y larga distancia, que permite a su vez la expansión de las ondas hertzianas, mediante las cuales se desarrolla la radiodifusión, la televisión y la prestación de los servicios de telecomunicaciones. El espectro electromagnético es un bien público, imprescriptible, inenajenable e inembargable, sujeto a la gestión y control del Estado, que forma parte del territorio colombiano y que es propiedad de la Nación. Los particulares tienen acceso a su uso, en igualdad de condiciones y oportunidades, en los términos que fije la Ley, sin que para dicho acceso se apliquen, de manera absoluta, las reglas que gobiernan el sistema de libre iniciativa, en la medida en que, por tratarse de un bien público, la gestión del espectro está sujeta a una especial regulación por parte del Estado. (Subrayado y resaltado fuera del texto) (Corte Constitucional, 2010, p. 2).

\section{b. Concepto Constitucional de Bien Público.}

La Constitución Nacional de 1991, hace mención a diferentes tipos de propiedad, a saber, la propiedad privada, la propiedad del Estado y la propiedad pública, y específicamente frente al Espectro Electromagnético este se encuentra clasificado como un bien del Estado, no solo por el concepto y alcance de las disposiciones constitucionales que lo definen, sino por el tratamiento que se le ha concedido, en cuanto se consideran son del Estado el subsuelo y los recursos naturales no renovables, el mar territorial, la zona contigua, la plataforma continental, la zona económica exclusiva, el espacio aéreo, el segmento de la órbita geoestacionaria, el espectro electromagnético Recordemos que nuestro Código Civil en su artículo 674, define los bienes de la Unión, como "aquellos que pertenecen a la República" (Congreso, 1887, p. 63), y a ello se ha referido sección cuarta de la sala de lo contencioso administrativo, al considerar:

De conformidad con el artículo 674 del Código Civil los “bienes de la Unión” se clasifican, en bienes patrimoniales o fiscales y en bienes de uso público. Los primeros son los propiamente estatales, pertenecen a una persona jurídica de derecho público de cualquier naturaleza y generalmente, están destinados a la prestación de las funciones públicas o de los servicios públicos, cuyo dominio corresponde al Estado, pero su "uso no pertenece generalmente a los habitantes", es decir, el Estado los posee y los administra de manera similar a como lo hacen los particulares con los bienes de su propiedad. En tanto que los bienes de uso público universal o bienes públicos del territorio son aquellos cuyo dominio es igualmente del Estado,

12 MENDOZA MARTELO, Gabriel, demanda de inconstitucionalidad parcial contra el parágrafo del artículo $1^{\circ}$, parágrafo del artículo $4^{\circ}$, numerales $4^{\circ}$ y 18 del artículo 22 e inciso último del artículo 72 de la Ley 1341 de 2009, Bogotá, D.C, 2010 
pero su uso pertenece a todos los habitantes del territorio y están a su servicio permanente (como las calles, plazas, parques, puentes, caminos, ejidos, etc.), lo que significa que, por su naturaleza, respecto a estos bienes ninguna entidad estatal tiene la titularidad de dominio equivalente a la de un particular, puesto que están destinados al servicio de todos los habitantes. Sobre ellos el Estado ejerce fundamentalmente derechos de administración y de policía, en orden a garantizar y proteger precisamente su uso y goce común, por motivos de interés general. Las características de los bienes de uso público, son: El titular del derecho de dominio es el Estado, representado por las respectivas entidades públicas que ejercen facultades especiales de administración, protección, control y de policía. Se encuentran determinados por la Constitución o por la Ley. Son bienes de dominio público que se caracterizan por su afectación a una finalidad pública, porque su uso y goce pertenecen a la comunidad, por motivos de interés general. Están sujetos a un régimen jurídico en virtud del cual gozan de privilegios tales como la inalienabilidad, inembargabilidad e imprescriptibilidad, que los colocan por fuera del comercio. (Consejo de Estado, 2003,p.1)

Así las cosas, el espectro electromagnético es un bien del Estado, de dominio público, por su afectación a la prestación del servicio público de televisión entre otros servicios, por ello el Estado al ser titular de dominio, ejerce la gestión, control y protección en los términos señalados por el artículo 75 de la Constitución Nacional.

La naturaleza del espectro electromagnético y radioeléctrico, como componente de aquel, hace que éste sea un bien jurídico distinto del servicio público que se presta a través de su uso y la actividad que despliega el Estado para su administración, gestión y control lo enmarca en el ejercicio de una función administrativa.

\section{c. Concepto Constitucional de Servicio Público.}

El Espectro radioeléctrico como componente del Espectro Electromagnético esta afecto a la prestación de servicios de telecomunicaciones, entre ellos el servicio público de televisión bajo la administración y reglamentación que fije el Estado; abarcando derechos y libertades, principios, el interés general, el marco de legalidad, pero esencialmente todo confluye en la satisfacción y cumplimiento de los fines y cometidos del Estado (Atheortúa Ríos, 2006, p. 17-19).

La Ley 142 de 1994,fija el régimen de los servicios públicos domiciliarios de acueducto, alcantarillado, aseo, energía eléctrica, distribución de gas combustible, telefonía fija pública básica conmutada y la telefonía local móvil en el sector rural; y " a los otros servicios previstos en normas especiales de la misma norma”. (Congreso, 1994, p.1-25).

Precisa que la intervención del Estado estará orientada a garantizar la libre competencia de conformidad con lo reglado por la Constitución Nacional en sus artículos 334, 336, y 365 a 370; y entre otros aspectos indica la posibilidad de que el acceso al espectro electromagnético para el servicio público de telecomunicaciones puede otorgarse por medio de un contrato de concesión, bajo los preceptos de las normas de contratación pública y las Leyes especiales que rijan la materia.

Y de ahí que el servicio público de televisión deba analizarse bajo su régimen especial, el cual se detallará más adelante (Fajardo Muriel, 2003, p.99) 


\section{d. Concepto constitucional de libre competencia.}

Nuestra Constitución Nacional ${ }^{13}$ establece que la libre competencia es un derecho de todos que implica responsabilidades, imponiendo el bien común como limitante a las actividad económica e iniciativa privada que deben estar debidamente reglamentadas, concediendo el carácter de función social a las empresas, y dando facultades al legislador para para que evite el que se obstaculice su ejercicio imponiéndole el deber de controlar los abusos que surjan de posiciones dominantes

Pero ese derecho de todos a la libre competencia en el sentir y manejo jurisprudencial de que ha sido objeto, no puede ser considerado como un derecho absoluto, y de esta manera lo ha expresado la Honorable Corte Constitucional, en los siguientes términos:

Cuando la prestación de servicios públicos se cumple por intermedio de particulares, el desarrollo de su actividad está constitucionalmente amparado por las libertades económicas y en particular por la libertad de empresa, la iniciativa privada y la libre competencia, en los términos del artículo 333 de la Carta Política. Sin embargo, la misma norma reconoce que esos derechos pueden ser restringidos y señala expresamente que "la Ley delimitará el alcance de la libertad económica cuando así lo exijan el interés social, el ambiente y el patrimonio cultural de la Nación". (...)

Significa lo anterior que las restricciones a las libertades económicas han de tener origen y fundamento en la Ley, aun cuando ello no excluye la intervención de otras autoridades para regular su ejercicio. En este sentido, refiriéndose justamente a la prestación de servicios públicos domiciliarios, la Corte ha advertido que "en el Estado Social de Derecho la libertad económica no es de carácter absoluto, por cuanto "además de la empresa, la propiedad también es una función social (Art. $58 \mathrm{CP}$ ) y (...) la libertad económica y la iniciativa privada tienen su garantía y protección supeditadas al predominio del interés colectivo (Art. $333 \mathrm{CP}$ ). Con base en ello la Corte ha precisado que, "en consecuencia su ejercicio está sometido no sólo a las pautas generales que fije el legislador, a las políticas generales de administración y control de eficiencia de los servicios públicos domiciliarios que dicte el Presidente, sino también a las directrices que les señalen las Comisiones de Regulación” (subrayado y resaltado fuera del texto) (Corte Constitucional, 2013, p.23)

La jurisprudencia de la Honorable Corte Constitucional en pronunciamiento posterior, y ya referido al servicio público de televisión, indicó:

La Corte también destacó que la autonomía del régimen de libre competencia implica que puede ser regulado "con independencia del régimen de los diferentes servicios o actividades económicas". Y para el caso que fue objeto de examen concluyó que si bien la Comisión Nacional de Televisión era - en aquel entonces- la autoridad encargada de regular la política de

13 Constitución Nacional artículo 333. La actividad económica y la iniciativa privada son libres, dentro de los límites del bien común. Para su ejercicio, nadie podrá exigir permisos previos ni requisitos, sin autorización de la Ley.

La libre competencia económica es un derecho de todos que supone responsabilidades.

La empresa, como base del desarrollo, tiene una función social que implica obligaciones. El Estado fortalecerá las organizaciones solidarias y estimulará el desarrollo empresarial.

El Estado, por mandato de la Ley, impedirá que se obstruya o se restrinja la libertad económica y evitará o controlará cualquier abuso que personas o empresas hagan de su posición dominante en el mercado nacional.

La Ley delimitará el alcance de la libertad económica cuando así lo exijan el interés social, el ambiente y el patrimonio cultural de la Nación. 
televisión, ello no implicaba que "todo" lo que estuviera relacionado con la prestación del servicio necesariamente afectara el ejercicio de sus funciones. Insistió en que "el Legislador es libre de establecer la autoridad pública encargada de velar por el estricto cumplimiento de las normas legales en punto de la libre y leal competencia económica", porque la asignación de funciones "no está predeterminada por la Constitución", pudiendo entonces encomendarlas a una o varias autoridades administrativas. En palabras de la Corte:

(...)

En todo caso, la competencia económica libre y leal, como principio constitucional y legal, como objeto del derecho, tiene autonomía y admite ser tratado con independencia del régimen de los diferentes servicios o actividades económicas. Desde este punto de vista, el hecho de que corresponda a la Comisión Nacional de Televisión trazar y dirigir la política de la televisión, según lo determine la Ley, en modo alguno significa que todo lo que ataña a los operadores de este servicio necesariamente comprometa el ejercicio de sus funciones. Estos sujetos son además destinatarios del resto del ordenamiento jurídico y, por serlo, se relacionan de manera distinta con múltiples procedimientos y autoridades. Como operadores económicos, actores del mercado de un servicio, no escapan a las reglas de la competencia leal y libre y, por consiguiente, a las autoridades instituidas por la Ley para hacer efectivas las obligaciones y deberes de este régimen". (Resaltado fuera de texto)"14 (Corte Constitucional, 2014, p.29).

\section{e. Principios Constitucionales.}

Entendemos por principios constitucionales aquellos mandatos de optimización que deben ser cumplidos atendiendo las condiciones políticas, económicas, sociales y jurídicas de un Estado; "son los llamados a garantizar en últimas la primacía de la Justicia material sobre el ordenamiento jurídico", "son mandatos que permiten o prohíben algo; forman parte del mundo de los deberes”. (Daza Duarte \& Quinche Pinzón, 2012, p. 6-8).

Respecto a los principios constitucionales, han de ser considerados para el análisis que nos ocupa, no solo porque estamos en un Estado social de derecho con las connotaciones que lo caracterizan, sino por los fines mismos del Estado y sus autoridades, las responsabilidades que tenemos particulares y autoridades, entre otros, esencialmente: el fundamental del debido proceso, los derechos económicos y sociales, la propiedad privada, el espectro electromagnético y su intervención, la dirección en materia de televisión. (Paz Martínez, 2006, p.3-5)

Igualmente han de tenerse presentes los principios orientadores de la función administrativa constitucionalmente consagrados en su capítulo quinto, artículo 209, esto es igualdad, moralidad, eficacia, economía, celeridad, imparcialidad y publicidad, imponiendo el que dicha función siempre debe ejercerse o materializarse en miras de satisfacer el interés general, así como el deber de que todas las autoridades coordinen y se colaboren en ejercicio de sus funciones las cuales deben gozar de autocontrol.

\subsection{Normas técnicas internacionales.}

Una norma técnica es un documento aprobado por un organismo reconocido que establece especificaciones técnicas basadas en los resultados de la experiencia y del desarrollo tecnológico,

14 Corte Constitucional. Expediente D-9827. Demanda de inconstitucionalidad contra los artículos 2 y 6 (parciales) de la Ley 1340 de 2009 , "por medio de la cual se dictan normas en materia de protección a la competencia”. Magistrado Ponente: Jorge Iván Palacio Palacio. 
que hay que cumplir en determinados productos, procesos o servicios. (Universidad de Alcalá, concepto.)

De ahí que resulta necesario referirnos al Reglamento de la Unión Internacional de Telecomunicaciones -UIT- de la cual forma parte la República de Colombia. ${ }^{15}$, adoptado por la Organización de las Naciones Unidas mediante un convenio suscrito por todos sus miembros, dicho organismo fue fundado en Paris en 1865 con el nombre de Unión Telegráfica Internacional, en 1934 adoptó su nombre actual, y en 1947 se convirtió en organismo especializado de las Naciones Unidas. (Organizacion Internacional de Telecomunicaciones-ITU-, 2014)

La Unión Internacional de Telecomunicaciones -UIT- es el organismo especializado de las Naciones Unidas para las Tecnologías de la Información y la Comunicación -TIC-; y dentro de sus funciones les corresponde "atribuir" el espectro radioeléctrico y órbitas satelitales en todo el mundo, función que materializan a través de le expedición de disposiciones de carácter técnico con base en las cuales se busca que interconectar mundialmente las redes y tecnologías existentes, propendiendo por garantizar el acceso a las mismas por parte de las comunidades y regiones más apartadas y menos favorecidas, al considerar como fundamental el derecho de la población a comunicarse. Y adicionalmente asumiendo las Tic como una herramienta de desarrollo económico, generador de educación, negocios, atención en salud, prestación de los servicios públicos y en general una plataforma de la economía mundial. (Unión Internacional de Telecomunicaciones UIT)

De esta organización mundial hacen parte ciento noventa y tres Estados que representan el sector público, instituciones de carácter académico y alrededor de setecientas compañías prestatarias de servicios de tecnología; y siempre buscando interactuar basados en la cooperación entre Estados, garantizan el respeto que cada uno tiene en ejercicio de su soberanía para reglamentar sus Tic, y emitiendo normas de carácter general entre las cuales podemos citar por su incidencia en nuestro análisis, las siguientes que hacen parte del referido convenio:

a) Efectuará la distribución de las frecuencias del espectro radioeléctrico y llevará el registro de las asignaciones de frecuencias, a fin de evitar toda interferencia perjudicial entre las estaciones de radiocomunicación de los distintos países.

b) Coordinará los esfuerzos para eliminar toda interferencia perjudicial entre las estaciones de radiocomunicación de los diferentes países y mejorar la utilización del espectro de frecuencias radioeléctricas.

c) Fomentará la colaboración entre sus miembros y asociados con el fin de llegar, en el establecimiento de tarifas, al nivel mínimo compatible con un servicio de buena calidad y con una gestión financiera de las telecomunicaciones sana e independiente.

d) Se reconoce la conveniencia de limitar el número de frecuencias y el espacio del espectro utilizado al mínimo indispensable para asegurar de manera satisfactoria el funcionamiento de los servicios necesarios, y para ello habrá de aplicarse los adelantos técnicos existentes.

e) Define el servicio de radiodifusión como un servicio de radiocomunicación cuyas emisiones se destinan a ser recibidas directamente por el público en general, el cual comprende emisiones sonoras, de televisión o de otro género.

15 UNIÓN INTERNACIONAL DE TELECOMUNICACIONES (UIT) Protocolo final al Convenio Protocolos adicionales al Convenio Resoluciones, Recomendación y Votos MONTREUX, Secretaria General de la Unión Internacional de Telecomunicaciones GINEBRA. Esta versión electrónica (PDF) ha sido escaneada por el Servicio de Biblioteca y Archivos. Ginebra 1965 
En desarrollo de su función de reglamentación técnica cuenta con un manual técnico de manejo y atribución del espectro electromagnético y su comprobación parametrizada como herramienta de referencia pala los Estados, la academia y cualquier interesado. (Unión Internacional de Telecomunicaciones UIT, p. 16-646)

\subsection{Normas, disposiciones y conceptos inherentes al sector de las Tecnologías de la Información y las Comunicaciones.}

Entendiendo por estas el conjunto de disposiciones que gobiernan la prestación de los servicios inherentes a las tecnologías de la información y las comunicaciones y que tienen su sustento constitucional legal y reglamentario.

La sociedad de las Tecnologías de la Información y las Comunicaciones a nivel mundial viene evolucionando y Colombia no ha sido la excepción a esa dinámica ni al desarrollo que ello genera; es así como podemos evidenciar amplios avances en proyectos de telecomunicaciones sociales, internet en banda ancha, tecnologías de última generación, aplicaciones, comunicaciones móviles, radio, y televisión, entre otros.

Sin embargo, vamos a concretar nuestro análisis en la regulación relativa al "servicio público de televisión con cubrimiento nacional que es prestado por operadores privados" seleccionados a través de Licitación Pública, para adjudicación de las concesiones por el tiempo determinado en la Ley, análisis en el que debemos mencionar la reglamentación inherente al espectro electromagnético; y de manera más específica a los requerimientos y elementos constitutivos del proceso de selección, para con ello poder determinar si ¿La licitación pública como proceso de selección para adjudicar las concesiones del servicio público de televisión abierta de operación nacional y del espectro electromagnético a los operadores privados; vulnera el principio de libre competencia?

Nos referiremos específicamente al servicio público de televisión y a las concesiones a través de las cuales se otorga a particulares la prestación de este, que cuentan con una reglamentación especial, que contienen la identificación de los elementos que conforman el proceso de selección objetiva de los concesionarios u operadores privados, así como los requisitos que estos deben cumplir, los cuales son ampliamente disimiles a los de otro tipo de contratación, todo ello en torno al principio de la libre competencia como principio constitucional, para validar si éste está siendo garantizado.

Este análisis es importante en razón a que a la fecha el servicio público de televisión abierta, sigue siendo prestado por los operadores incumbentes de operación privada ${ }^{16}$, habiéndose prorrogado las concesiones existentes, no siendo esta una prerrogativa del concesionario sino un hecho excepcional $^{17}$; y pese a que el Estado Colombiano generó desde el año 2008 durante la existencia de la hoy liquidada Comisión Nacional de Televisión (CNTV), reemplazada por la Autoridad Nacional de Televisión (ANTV), la expectativa respecto a la potencial existencia de un

16 CNTV Comisión Nacional de Televisión hoy liquidada, adjudicó a Caracol Televisión S.A., y a RCN Televisión S.A., la concesión para la operación y explotación de dos canales de televisión de operación privada de cubrimiento nacional por un plazo inicial de diez años, contados a partir de la fecha de inicio de operación comercial, los cuales han sido a la fecha prorrogados por un lapso igual; habiéndose pactado en los mismos la cláusula de exclusividad Bogotá, 1997.

17 PRETELT CHALJUB, José Ignacio Corte Constitucional, Sentencia C-300. Bogotá, 2012. 
tercer, cuarto y/o quinto canal(es); habiéndose generado los consecuentes procesos de selección objetiva amparados en el régimen especial aplicable en cada oportunidad, se han declarado fallidos por diferentes causas, que revisaremos en su oportunidad; ahondando en aspectos relevantes tales como las exigencias establecidas en la Ley de Tics para efectos de asignación del uso del espectro electromagnético como elemento indispensable para la prestación de dicho servicio, el análisis de las implicaciones de esas exigencias sumadas a las que conlleva el cumplimiento de los requisitos del Registro Único de Operadores, la participación de inversión extranjera, entre otros aspectos particulares en garantía del principio de Libre Competencia, hechos que deben verificarse igualmente frente a las limitantes contempladas como inhabilidades de los concesionarios incumbentes y sus socios o miembros. De ahí que pretendemos poder generar un análisis académico que nos permita determinar si dentro del mercado y agentes económicos de la televisión abierta con operadores privados, existen garantías, restricciones o limitantes al ejercicio de la Libre Competencia.

En la actualidad al existir operadores incumbentes en la operación privada del servicio público de televisión abierta con cubrimiento nacional; surge el interrogante de si en la práctica los esfuerzos del Gobierno Nacional por adjudicar uno o más canales de operación privada están limitados o no por el mismo procedimiento de selección de esos operadores que en todo apuntan a dar cumplimiento de los dispuesto por la Ley 1341 de 2009, más conocida como la Ley de Tics en su artículo $2^{\circ}$, en cuanto plantea como uno de sus postulados orientadores el de la Libre competencia que incentive entre otros: la concurrencia al mercado, con observancia del régimen de competencia, bajo precios de mercado y en condiciones de igualdad; la Neutralidad Tecnológica, que permitan garantizar la libre y leal competencia, y que su adopción sea armónica con el desarrollo ambiental sostenible; podríamos decir que realmente hay libre competencia a hoy?

Para poder ahondar en estos temas es importante mencionar que en nuestro país, el programa de Gobierno "Prosperidad Para Todos", trazado en el Plan Nacional de Desarrollo 20102014,,más empleo, menos pobreza y más seguridad, consignado en la Ley 1450 de 2010, prevé que le corresponde al Ministerio de Tecnologías de la Información y Comunicaciones (Mintic) definir el modelo eficiente de gestión para el financiamiento, la administración, la operación, el mantenimiento y la explotación de la red pública de televisión que garantice su sostenibilidad, que reconozca las transformaciones de la industria de televisión y que optimice los recursos de su financiamiento; comprometiéndolo en el establecimiento de esquemas de generación de ingresos a partir de la prestación de servicios como el arrendamiento de infraestructura, la producción de contenidos, entre otros; modelo de gestión que debe considerar el sostenimiento de la red analógica de televisión y su modernización al estándar de Televisión Digital Terrestre (TDT), incluyendo el aprovechamiento de todas las ventajas que la misma permite. El diseño e implementación de la red digital de televisión pública deberá atender a criterios de eficiencia y planificación idónea, para lo cual integrará las redes de los operadores regionales de televisión. Además, para asegurar el funcionamiento de la Televisión Digital Terrestre (TDT), quienes están utilizando las frecuencias destinadas para tal fin, deben liberarlas de acuerdo con los tiempos establecidos por el Ministerio de TIC. Igualmente prevé ampliar la oferta de canales aprovechando tecnologías con altos niveles de penetración como telefonía móvil y televisión. (Departamento Nacional de Planeación-DNP,2010, p. p. 78101153155 157). 
Ahora bien, en el actual Plan Nacional de Desarrollo consagrado legalmente en la Ley 1753 de 2015 (junio 9) ${ }^{18}$ por la cual se expide el Plan Nacional de Desarrollo 2014-2018 "Todos por un nuevo país", el Congreso de la República de Colombia determinó frente al servicio público de televisión y el uso del espectro electromagnético, elementos que debemos importante mencionar por su novedad (DNP, 2015, P. 110-116):

- Haciendo uso de los recursos del Fondo para el Desarrollo de la Televisión y los Contenidos, destinadas por la Autoridad Nacional de Televisión (ANTV) a los canales públicos de televisión, se apoyará el desarrollo de contenidos digitales multiplataforma a los beneficiarios establecidos por las disposiciones vigentes. (artículo 39).

- Autoriza a que los permisos para el uso del espectro se otorguen por un plazo inicial de diez (10) años, incorporando la posibilidad de prorrogarlo por periodos iguales, indicando que ese periodo de renovación la autoridad competente habrá de considerar los aspectos determinados en el marco de legalidad ${ }^{19}$. (artículo 42).

- Igualmente se dispone en este plan de Gobierno, la promoción del desarrollo del servicio mediante tecnología satelital y DTH a cargo de la Autoridad Nacional de Televisión. Para esto, el Fondo de Desarrollo de la Televisión y los Contenidos podrá subsidiar equipos terminales, televisores, y paneles solares dirigidos a centros comunitarios y escuelas públicas en zonas apartadas del país; indicando que estos subsidios solo podrán otorgarse dentro del periodo de gobierno.(artículo 194)

Como hecho importante que precede a estos Planes Nacionales de Desarrollo, y que buscaba marcar un cambio radical en la administración por parte del Estado sobre el servicio de Televisión en Colombia, debemos mencionar la liquidación de la Comisión Nacional de Televisión - CNTV- y su reemplazo por la Autoridad Nacional de Televisión -ANTV-, como una Agencia Nacional Estatal de Naturaleza Especial, del Orden Nacional, con personería jurídica, autonomía administrativa, patrimonial, presupuestal y técnica, la cual forma parte del sector de las Tecnologías de la Información y las Telecomunicaciones.

La ANTV está conformada por una Junta Nacional de Televisión, que está apoyada financieramente por el Fondo para el Desarrollo de la Televisión (FONTV); como organismo rector en el manejo del servicio ya sea brindado por operadores públicos o privados; modificación que se dispuso mediante la Ley 1341 de 2009, la cual a su vez se ocupa de determinar el marco general para la formulación de las políticas públicas que rigen actualmente el sector de las Tecnologías de la Información y las Comunicaciones, su ordenamiento general, el régimen de competencia, la protección al usuario, así como lo concerniente a la cobertura, la calidad del servicio, la promoción de la inversión en el sector y el desarrollo de estas tecnologías, el uso eficiente de las redes y del espectro radioeléctrico, así como las potestades del Estado en relación con la planeación, la gestión, la administración adecuada y eficiente de los recursos, regulación, control y vigilancia del mismo y facilitando el libre acceso y sin discriminación de los habitantes del territorio nacional a la Sociedad de la Información.

18 Diario oficial 49538 Bogotá 2015

19 Artículo 42. Plazo y renovación de los permisos para el uso del espectro radioeléctrico. Modifíquese el primer inciso del artículo 12 de la Ley 1341 de 2009, el cual quedará así: "Artículo 12. Plazo y renovación de los permisos para el uso del espectro radioeléctrico. El permiso para el uso del espectro radioeléctrico tendrá un plazo definido inicial hasta de diez (10) años, el cual podrá renovarse a solicitud de parte por períodos de hasta diez (10) años. Para determinar el periodo de renovación, la autoridad competente tendrá en cuenta, entre otros criterios, razones de interés público, el reordenamiento nacional del espectro radioeléctrico, o el cumplimiento a las atribuciones y disposiciones internacionales de frecuencias, la determinación deberá efectuarse mediante acto administrativo motivado". 
La referida disposición determina en su artículo $1^{\circ}$ que el servicio de televisión continuará rigiéndose por las normas especiales pertinentes, con las excepciones específicas que contenga la misma norma, remitiéndonos de inmediato a lo reglado en las Leyes 182 de 1995, 335 de 1996, 506 de 1999, 680 de 2001, 1507 de 2012. La Ley de Tics fue expedida como consecuencia del Acto Legislativo 002 de 2001 por medio del cual los artículos 76 y 77 de la Constitución Nacional fueron derogado el primero y el segundo modificado; igualmente la norma ibídem establece la distribución de competencias entre las entidades del Estado en materia de televisión y se dictan otras disposiciones; todo ello de manera concordante con las funciones previstas en las Leyes precedentemente mencionadas.

\subsection{Conceptos legales relevantes para identificar el servicio público de televisión prestado a nivel nacional por operadores privados.}

Nos referiremos a aquellos preceptos, elementos o palabras que son de uso y aplicación frecuente en el tema por su injerencia y hacen parte del tema objeto de investigación.

a. Televisión: Es un servicio público de telecomunicaciones, ${ }^{20}$ sujeto a la titularidad, reserva, control y regulación del Estado, cuya prestación se materializa, mediante concesión, a las entidades públicas a que se refiere esta Ley, a los particulares y comunidades organizadas, en los términos del artículo 365 de la Constitución Política.( Ley 182,art $1^{\circ}$ )

b. Fines del servicio público de televisión: Son formar, educar, informar veraz y objetivamente y recrear de manera sana. $(\operatorname{art} .2)^{21}$

c. Clasificación del servicio y sus criterios ${ }^{22}$ :

- Tecnología principal de transmisión o medio utilizado para distribuir la señal.

- Usuarios del servicio o destinación de las señales emitidas.

- Orientación general de la programación emitida;

- Niveles de cubrimiento del servicio.

d. Espectro Electromagnético: Constitucional y legalmente se encuentra definido como un bien público, inajenable e imprescriptible, sujeto a la gestión y control del Estado a través de la Agencia Nacional del Espectro y el Ministerio de Tecnologías de la Información y las Comunicaciones, para efectos del servicio público de televisión. Constitución Nacional, artículos 75 y 76, Ley 182 de 1995 artículo 23 y siguientes.

e. Espectro radioeléctrico: Acudimos a hacer uso de la definición técnica que nos suministra la Agencia nacional del Espectro - ANE-, en el siguiente contexto general de Tic (Agencia Nacional del Espectro ANE, 2014), así:

El espectro radioeléctrico se trata del medio por el cual se transmiten las frecuencias de ondas de radio electromagnéticas que permiten las telecomunicaciones (radio, televisión,

20 Técnicamente, es un servicio de telecomunicaciones que ofrece programación dirigida al público en general o a una parte de él, que consiste en la emisión, transmisión, difusión, distribución, radiación y recepción de señales de audio y video en forma simultánea.Este servicio público está vinculado intrínsecamente a la opinión pública y a la cultura del país, como instrumento dinamizador de los procesos de información y comunicación audiovisuales.

21. Los fines del servicio de televisión son formar, educar, informar veraz y objetivamente y recrear de manera sana. Con el cumplimiento de los mismos, se busca satisfacer las finalidades sociales del Estado, promover el respeto de las garantías, deberes y derechos fundamentales y demás libertades, fortalecer la consolidación de la democracia y la paz, y propender por la difusión de los valores humanos y expresiones culturales de carácter nacional, regional y local.

22 Ley 182 de 1995 artículo18 y siguientes. 
Internet, telefonía móvil, televisión digital terrestre, etc.), y son administradas y reguladas por los gobiernos de cada país.

La definición precisa del espectro radioeléctrico, tal y como la ha definido la Unión Internacional de Telecomunicaciones (UIT), es: "Las frecuencias del espectro electromagnético usadas para los servicios de difusión y servicios móviles, de policía, bomberos, radioastronomía, meteorología y fijos." Este "(...) no es un concepto estático, pues a medida que avanza la tecnología se aumentan (o disminuyen) rangos de frecuencia utilizados en comunicaciones, y corresponde al estado de avance tecnológico. (Unión Internacional de Telecomunicaciones-UIT-, 2011)

f. Cuadro Nacional de Frecuencias: Es el registro público y actualizado que se lleva por parte de la Agencia Nacional del Espectro -ANE-, que de conformidad con las normas internacionales estén atribuidas para la prestación del servicio público de televisión, en el cual se evidencia las frecuencias concedidas, disponibles, los términos de concesión y sanciones que se hayan impuesto a los operadores si llegaren a presentarse. En cuanto a las ya concesionadas o que se encuentran en uso por parte de operadores privados del servicio público de televisión, no entramos a verificar este aspecto en la medida en que el presente análisis se centra en la competencia no entre el mercado incumbentes sino de estos frente a los nuevos operadores. (UIT-, 2011)

g. Atribución (de una banda de frecuencias): Inscripción en el Cuadro de atribución de bandas de frecuencias, de una banda de frecuencias determinada, para que sea utilizada por uno o varios servicios de radiocomunicación terrenal o espacial o por el servicio de radioastronomía en condiciones especificadas. Este término se aplica también a la banda de frecuencias considerada. (UIT, 2013)

h. Adjudicación (de una frecuencia o de un canal radioeléctrico): Inscripción de un canal determinado en un plan, adoptado por una conferencia competente, para ser utilizado por una o varias administraciones para un servicio de radiocomunicación terrenal o espacial en uno o varios países o zonas geográficas determinados y según condiciones especificadas. (ANE, 2014) ${ }^{23}$

i. Asignación (de una frecuencia o de un canal radioeléctrico): Autorización que da una administración para que una estación radioeléctrica utilice una frecuencia o un canal radioeléctrico determinado en condiciones especificadas. (ANE, 2015)

j. Administración: Todo departamento o servicio gubernamental responsable del cumplimiento de las obligaciones derivadas de la Constitución de la Unión Internacional de Telecomunicaciones, del Convenio de la Unión Internacional de Telecomunicaciones y de sus Reglamentos Administrativos (UIT, 2014)

\subsection{Competencias del Estado y sus entidades orientadas a la intervención, gestión y control del Espectro Electromagnético y del Servicio Público de Televisión.}

\section{a. Ministerio de Tecnologías de la Información y las Comunicaciones - MINTIC-}

Sus objetivos y funciones, son las descritas en la Ley 1341 artículo 15 y siguientes, orientadas a diseñar, formular, adoptar y promover las políticas, planes, programas y proyectos de todo el

23 Obligación derivada de la Constitución de la Unión Internacional de Telecomunicaciones, del Convenio de la Unión Internacional de Telecomunicaciones y de sus Reglamentos Administrativos (CS 1002) 
sector de Tics, basado en principios constitucionales; generando uso, apropiación, fortalecimiento y desarrollo del país basados en las Tics. ( 2009)

Sin embargo las políticas frente a la gestión, planeación y administración del espectro radioeléctrico relativos al servicio público de televisión la ejerce la Agencia Nacional del Espectro -ANE-, soportados obviamente en las orientaciones que dicte el Gobierno Nacional.

Igualmente, administra el régimen de contraprestaciones y otras actuaciones administrativas que comporten el pago de derechos, mediante el desarrollo de las operaciones de liquidación, cobro y recaudo, de conformidad con la legislación vigente.

Ahora bien, la Ley 1341 en su título II frente al acceso a recursos escasos, determina en sus artículo 11, que para poder hacer "uso" del espectro radioeléctrico requiere permiso previo, expreso y otorgado por el Ministerio de Tecnologías de la Información y las Comunicaciones, y que dicho permiso debe concederse respetando la neutralidad en la tecnología, sin generar interferencias sobre otros servicios; para lo cual dicho Ministerio debe adelantar el mecanismo de selección objetiva, a través de convocatoria pública, y que solo podrá otorgarse dicho permiso de uso en forma directa, cuando prime la continuidad del servicio y solo por el término estrictamente necesario para que la Administración convoque un proceso de selección objetiva, tal como lo analizó y determinó exequible la Corte Constitucional mediante Sentencia C-403 (Corte Constitucional, 2010)

Igualmente prevé que el Gobierno Nacional pueda asignar permiso libre para el uso de frecuencias de acuerdo con las recomendaciones de la UIT; adicionalmente a dichos permisos de uso se podrán generar igualmente actos de cesión, cuya autorización está sujeta a que el Ministerio verifique que con ello no se desmejoran los requisitos, calidad y garantías del uso, acceso y beneficio común del espectro.

Igualmente en el artículo 12, la norma ibídem, determina que ese permiso de "uso" se concede por un término definido de diez (10) años y autoriza para que pueda ser objeto de renovación a solicitud de parte con tres(3) meses de antelación a su vencimiento so pena de entenderse no renovado; esa renovación podrá otorgarse por períodos iguales al plazo inicial, basados en "razones de interés público, o cuando resulte indispensable el reordenamiento nacional del espectro radioeléctrico, o para dar cumplimiento a las atribuciones y disposiciones internacionales de frecuencias, el plazo de renovación podrá ser inferior al plazo inicial.”. (2009)

Como ya lo expresamos el actual Plan Nacional de Desarrollo consagrado en la Ley 1753 de $2015^{24}$ por la cual se expide el Plan Nacional de Desarrollo 2014-2018, contiene iguales previsiones frente a la renovación, pero especifica en su artículo 42 que "la determinación deberá efectuarse mediante acto administrativo motivado" 25 , y abre la opción a que puedan basarse en otras razones, al indicar "Para determinar el periodo de renovación, la autoridad competente

24 Diario oficial 49538 Bogotá, 9 de junio de 2015

25 Artículo 42. Plazo y renovación de los permisos para el uso del espectro radioeléctrico. Modifíquese el primer inciso del artículo 12 de la Ley 1341 de 2009, el cual quedará así: "Artículo 12. Plazo y renovación de los permisos para el uso del espectro radioeléctrico. El permiso para el uso del espectro radioeléctrico tendrá un plazo definido inicial hasta de diez (10) años, el cual podrá renovarse a solicitud de parte por períodos de hasta diez (10) años. Para determinar el periodo de renovación, la autoridad competente tendrá en cuenta, entre otros criterios, razones de interés público, el reordenamiento nacional del espectro radioeléctrico, o el cumplimiento a las atribuciones y disposiciones internacionales de frecuencias, la determinación deberá efectuarse mediante acto administrativo motivado". Bogotá.2015 
tendrá en cuenta, entre otros criterios"; mientras el referido artículo 12 tiene un sentido restrictivo de las causas, indicando adicionalmente que las condiciones de renovación deben ser razonables, no discriminatorias y compatibles con el desarrollo tecnológico, la continuidad del servicio y los incentivos adecuados para la inversión; prohibiendo el que la renovación sea automática o gratuita. (DNP, 2015, p. 73)

Dicho "permiso de uso del espectro radioeléctrico", por cualquier proveedor de redes y servicios de telecomunicaciones genera el pago de contraprestación económica a favor del Fondo de las Tecnologías de la Información y las Comunicaciones -FONTIC-. valor que por competencia legal de acuerdo con el artículo 13 de la Ley 1341, lo fija mediante resolución el Ministro de Tecnologías de la Información y las Comunicaciones -MINTIC. (2014, p.22).

Lo anterior basados en parámetros como: ancho de banda asignado, el número de usuarios potenciales, la disponibilidad del servicio, los planes de expansión y cobertura y la demanda por el espectro y su disponibilidad, y cualquier otro parámetro técnico que sirva como indicador del precio que deba recibir el Estado por la utilización del espectro radioeléctrico"; parámetros que compete estudiar y proponer a la ANE de acuerdo con el numeral $7^{\circ}$ del artículo 26 de la Ley 1341. (2009).

Dicha contraprestación económica para efectos de renovación es potestativa de determinación y administración por parte del Mintic; y se causa en favor del FONDO TIC; debiéndose pagar de forma anticipada cada año, salvo que se estipule regla especial o diferente en los procesos objetivos de renovaciones.

El Decreto 1161 de $2010^{26,}$ el cual fija el régimen "unificado de contraprestaciones”, define:

Permiso: Acto administrativo que faculta a una persona natural o jurídica, pública o privada, para usar, explotar y/o gestionar total o parcialmente una o varias porciones específicas del espectro radioeléctrico, por un término definido. (Subrayado y resaltado fuera del texto).

En lo referente a la determinación de la contraprestación correspondiente a las frecuencias atribuidas por el Ministerio de Tecnologías de la Información y las Comunicaciones al servicio de televisión, determina que dicha competencia está en cabeza de la -CNTV- hoy liquidada, entiéndase ANTV. (2012, p.1). (De la Quadra, Fernandez del Castillo, \& Vida Fernández, 2009, p. 486).

\section{b. Agencia Nacional del Espectro-ANE-}

Desde la expedición del Acto Legislativo 002 de 2011 por medio del cual, se derogó el artículo 76 de la Constitución Nacional, se determinó que "La intervención estatal en el espectro electromagnético utilizado para los servicios de televisión, estará a cargo de un organismo de derecho público con personería jurídica, autonomía administrativa, patrimonial y técnica, sujeto a un régimen legal propio", disposición que dio origen a la creación de la Agencia Nacional del Espectro, mediante la Ley 1341 de 2009 en su artículo 25 y siguientes, y posteriormente el

26 Diario Oficial 47.679 de abril 13 de 2010 
Decreto 4169 de 201127, modificó su naturaleza y reasignó algunas funciones, determinándose como elementos esenciales para nuestro tema, los siguientes aspectos, así:

$1^{\circ}$ Las funciones relativas a la planeación y atribución del espectro radioeléctrico, así como las inherentes al establecimiento, el mantenimiento actualizado del Cuadro Nacional de Atribución de Bandas de Frecuencias -CNABF- y la elaboración de los Cuadros de Características Técnicas de la Red -CCTR-, para la asignación de frecuencias, se asignan a la Agencia Nacional del Espectro -ANE-; ya que anteriormente la Entidad fue creada sin personería jurídica y este Decreto cambio su naturaleza otorgándosela y dándole el nivel técnico que actualmente ejerce con plena autonomía en todo orden. Dichas funciones estaban en cabeza del Ministerio de Tecnologías de la Información y las Comunicaciones de acuerdo con la Ley 1341.

$2^{\circ}$ La Agencia Nacional del Espectro funge actualmente como soporte técnico para la gestión, planeación y ejercicio de la vigilancia y control del espectro radioeléctrico y en consecuencia ejecuta además de las funciones establecidas en la Ley 1341, las siguientes:

- Planea y atribuye el espectro radioeléctrico con sujeción a las políticas y lineamientos que determine el Ministerio de Tecnologías de la Información y las Comunicaciones.

- Prepara y propone al Ministerio de Tecnologías de la Información y las Comunicaciones los Cuadros de Características Técnicas de la Red -CCTR-

- Formula y ejecuta programas de investigación, conocimiento y divulgación del espectro radioeléctrico.

$3^{\circ}$ El actual Plan Nacional de Desarrollo contenido en la Ley 1753 de 2015 en sus artículos 41, 42 y 43, la Ley 1341, y los Decretos 093 de 2010 y 4169 de 2011, consagran el marco de competencia del Agencia frente al Espectro Electromagnético; siendo importante destacar que dichas funciones deben ejecutarse bajo las políticas que al respecto determine el Gobierno Nacional a través del MINTIC.

$4^{\text {O }}$ Por disposición expresa de la Ley 1341 de 2009 en su numeral 4 del artículo 26, a la ANE le corresponde ejercer la vigilancia y control del espectro radioeléctrico, con excepción de lo dispuesto en el artículo 76 de la Constitución Política, esto es el Espectro asignado para la prestación del servicio público de televisión.

$5^{\circ}$ Como competencia exclusiva en cabeza del Ministerio de TIC se encuentra la relativa a la "asignación de frecuencias del espectro", tal como lo prevé el parágrafo del artículo 26 de la Ley 1341.

$6^{\circ}$ De conformidad con la Ley 1507 de 2012, se puntualiza que la intervención estatal en el espectro electromagnético destinado a los servicios de televisión, estará a cargo de la Agencia Nacional del Espectro -ANE- de conformidad con lo determinado en la Ley 1341 y el Decreto-Ley 4169 de 2011. En particular, la ANE ejercerá las funciones previstas en los artículos 24, 26 y 27 de la Ley 182.

La Autoridad Nacional de Televisión -ANTV-, será la encargada de asignar las frecuencias que previamente haya atribuido la Agencia Nacional del Espectro (ANE) para la operación del servicio de televisión.

\section{c. Autoridad Nacional de Televisión - ANTV-}

27 Publicado en el Diario Oficial 48242 de noviembre 3 de 2011. 
El Acto Legislativo 002 de 2011, igualmente determinó en sus artículos primero y tercero transitorio, modificar el artículo 76 de la Constitución Nacional, en el sentido de establecer que el Congreso de la República expediría la Ley que fijaría la política en materia de televisión, expidiéndose la Ley 1507 de 2012, creando la Autoridad Nacional de Televisión -ANTV-, ordenando la liquidación de la anterior Comisión Nacional de Televisión -CNTV- y estableciendo la distribución de competencias en materia de televisión; siendo relevante mencionar, las siguientes:

$1^{\mathrm{o}}$ Esta norma al estar creada y debidamente reglamentada la Agencia Nacional del Espectro -ANE-, en cuanto a su objeto fines y funciones-, excluye a estas de la competencia de la nueva Autoridad Nacional de Televisión.

$2^{\circ}$ No derogo totalmente la Ley de televisión contenida en la Ley 182 de 1995, sino solo en lo que sea contrario; manteniendo el concepto relativo a que la Televisión es un servicio público de competencia de la Nación, bajo un marco de derechos principios libertades, primando siempre el interés general, la legalidad, la libre competencia entre otros que ya hemos revisado en el componente constitucional.

$3^{\circ} \mathrm{Y}$ su componente fundamental fue el de separar y reasignar funciones relativas al servicio público de televisión entre el MINTIC-, y la nueva Autoridad de Televisión.

$4^{\text {o }}$ Dentro de sus funciones generales, y de interés para el tema del que tratamos, la Ley asigno las funciones que a continuación se relacionan y que determina la Ley 1507 de 2012, así:

- Adjudicar las concesiones y licencias de servicio, espacios de televisión, de conformidad con la Ley.

- Coordinar con la ANE los asuntos relativos a la gestión, administración y control del espectro radioeléctrico.

- Sancionar cuando haya lugar a quienes violen con la prestación del servicio público de televisión, las disposiciones constitucionales y legales que amparan específicamente los derechos de la familia y de los niños.

- Asistir, colaborar y acompañar en lo relativo a las funciones de la ANTV, al Ministerio de las Tecnologías de la Información y las Comunicaciones en la preparación y atención de las reuniones con los organismos internacionales de telecomunicaciones en los que hace parte Colombia.

- Asistir al Gobierno Nacional en el estudio y preparación de las materias relativas a los servicios de televisión.

- La ANTV será responsable ante el Congreso de la República de atender los requerimientos y citaciones que este le solicite a través de las plenarias y Comisiones.

- Velar por el fortalecimiento y desarrollo de la TV Pública.

- Promover y desarrollar la industria de la televisión.

$5^{\circ}$ La nueva Ley de televisión consagró en su artículo 22, la llamada transferencia supletiva de competencias, que consiste en que las funciones de la Comisión Nacional de Televisión que no fueron objeto de mención en la Ley 1507, se entenderán transferidas a la Autoridad Nacional de Televisión-ANTV-; por lo que es importante mencionar cuales no fueron objeto de esa transferencia de competencia , así:

- En materia de política pública indica que sin perjuicio de la potestad reglamentaria del Presidente de la República, todas las autoridades a que se transfieren funciones en virtud de la presente Ley 1507, ejercerán, en el marco de sus competencias, la función que de dirigir, ejecutar y desarrollar la política general del servicio de televisión determinada en la Ley y 
velar por su cumplimiento, función que anteriormente radicaba exclusivamente en cabeza de la Comisión Nacional de Televisión.

- En materia de control y vigilancia, la ANTV ejercerá las funciones de inspección, vigilancia y control orientadas a la adecuada prestación del servicio ${ }^{28}$, $\sin$ perjuicio de las actividades relacionadas con la dirección y manejo de la actividad concesional que en calidad de entidad concedente deba realizar la ANTV, de conformidad con el artículo 14 de la Ley de televisión, y de aquellas relacionadas con el control y vigilancia del espectro radioeléctrico para la prestación del servicio de televisión de acuerdo con el artículo 15 de la Ley 1507.

\section{d. La Comisión de Regulación de Comunicaciones - CRC-}

La Comisión de Regulación de Comunicaciones -CRC- a que se refiere el artículo 19 de la Ley 1341, se encuentra reglamentada por el Decreto 089 de 2010, es una Entidad adscrita al Ministerio de Tecnologías de la Información y las Comunicaciones, encargada: de promover la competencia, evitar el abuso de posición dominante y regular los mercados de las redes y los servicios de comunicaciones; con el fin que la prestación de los servicios sea económicamente eficiente, y refleje altos niveles de calidad. Estando obligada a adoptar una regulación que incentive la construcción de un mercado competitivo. (Presidencia de la República, 2010, p.2).

Las funciones taxativas se encuentran enunciadas en el artículo 22 de la Ley del sector de las Tic, la cual consagra una excepción especifica en materia de regulación, y esto es que no lo hace frente al accesos y uso de las redes y el acceso a los mercados de los servicios para servicios de televisión radiodifundida y radiodifusión sonora, hacia una regulación por mercados; ya que esta actividad la genera funcionalmente por competencias la ANTV.

Ahora bien, también le corresponde clasificar el servicio de televisión según los criterios relativos a: a) Tecnología principal de transmisión utilizada; b) Usuarios del servicio; c) Orientación general de la programación emitida, y d) Niveles de cubrimiento del servicio; contando con la facultad de incluir otros criterios de clasificación, así como igualmente le corresponde regular las condiciones de operación y explotación del servicio.

En particular, la CRC tendrá la función de establecer las prohibiciones a que se refiere el artículo 53 de la Ley $182^{29}$, salvo cuando se relacionen con conductas que atenten contra el pluralismo informativo, caso en el cual tales prohibiciones serán establecidas por la ANTV.

\section{e. La Superintendencia de Industria y Comercio -SIC-}

\footnotetext{
28 b) Adelantar las actividades de inspección, vigilancia, seguimiento y control para una adecuada prestación del servicio público de televisión. Para estos efectos, podrá iniciar investigaciones y ordenar visitas a las instalaciones de los operadores, concesionarios de espacios de televisión y contratistas de televisión; exigir la presentación de libros de contabilidad y demás documentos privados, sin que le sea oponible la reserva o inviolabilidad de los mismos; e imponer las sanciones a que haya lugar; Literal declarado EXEQUIBLE por la Corte Constitucional mediante Sentencia C-298 de 1999

29 Facultades sancionatorias de la Comisión Nacional de Televisión. La Comisión Nacional de Televisión establecerá prohibiciones para aquellas conductas en que incurran las personas que atenten contra el pluralismo informativo, la competencia, el régimen de inhabilidades y los derechos de los televidentes. La violación de las normas acarreará sanciones a los infractores o a quienes hayan resultado beneficiarios reales de tales infracciones. PAR.-Quienes participen en la violación del régimen de inhabilidades serán sancionadas por la comisión nacional de televisión, con multas de seiscientos (600) a seis mil (6.000) salarios mínimos legales mensuales vigentes a la fecha de la sanción. La Comisión Nacional de Televisión estará obligada a elevar denuncia de los anteriores casos ante las autoridades competentes.
} 
El Decreto 2153 de $1992^{30,}$ por medio del cual se reestructura la Superintendencia de Industria y Comercio, modificado por la Ley 1340 de $2009^{31}$, por la cual se dictan normas en materia de protección de la competencia, definen a esta Superintendencia como un organismo de carácter técnico, que goza de autonomía administrativa, financiera y presupuestal; siendo una de las funciones preponderantes a su cargo la determinada por el artículo 3 de la Ley 1340 de 2009, en cuanto debe velar por "la observancia de las disposiciones sobre protección de la competencia; atender las reclamaciones o quejas por hechos que pudieren implicar su contravención (...)para alcanzar en particular los siguientes propósitos: la libre participación de las empresas en el mercado, el bienestar de los consumidores y la eficiencia económica.." (Presidencia de la República, 1992, p.2-3).

Igualmente le corresponde imponer las sanciones pertinentes por: (i) violación de las normas sobre prácticas comerciales restrictivas y promoción de la competencia, (ii) por la inobservancia de las instrucciones que, en desarrollo de sus funciones imparta la Superintendencia.

Y asumió la competencia que se radicaba en la hoy liquidada CNTV, descrita en el literal d del artículo 5 de la Ley 182, en cuanto esta deberá:

Investigar y sancionar a los operadores, concesionarios de espacios y contratistas de televisión por violación del régimen de protección de la competencia, el pluralismo informativo y del régimen para evitar las prácticas monopolísticas previsto en la Constitución y en la presente y en otras Leyes, o por incurrir en prácticas, actividades o arreglos que sean contrarios a la libre y leal competencia y a la igualdad de oportunidades entre aquéllos, o que tiendan a la concentración de la propiedad o del poder informativo en los servicios de televisión, o a la formación indebida de una posición dominante en el mercado, o que constituyan una especie de práctica monopolística en el uso del espectro electromagnético y en la prestación del servicio. (1995)

\subsection{Procedimiento determinado por la Ley especial, para la asignación de las frecuencias radioeléctricas para el servicio público de Televisión.}

Vista la "intervención del Estado" en la gestión y control del espectro electromagnético asignado a la prestación del servicio público de televisión, ejercidos a través de diferentes entidades gubernamentales, con competencias claramente delimitadas, entraremos a detallar el procedimiento reglado especial que se aplica por expresa disposición legal como mecanismo de selección de los concesionarios prestatarios del servicio, y vamos a empezar por resaltar las connotaciones especiales contenidas en la Ley de $\operatorname{tic}^{32}$ y la normas compiladas que reglamentan el servicio ${ }^{33}$ para, posteriormente tocar el proceso general de contratación aplicable.

El proceso de selección del contratista, incluye no solo la adjudicación de una concesión para la prestación de un servicio público, sino la asignación de unas frecuencias para el mismo efecto, es necesario mencionar los conceptos y aspectos que frente al tema el procedimiento contempla el régimen especial; así:

30 Diario Oficial 40.704 de diciembre 31 de 1992.

31 Diario Oficial 47420 de julio 24 de 2009.

32 Ley 1341 de 2009.

33 Leyes 182 de 1995, 335 de 1996, 506 de1999, 680 de 2001 y 1507 de 2012 
La Ley especial define la televisión como un servicio público sujeto a la titularidad, reserva, control y regulación del Estado, cuya prestación corresponderá, mediante concesión, en los términos del artículo 365 de la Constitución Política; y lo concibe técnicamente como un servicio de telecomunicaciones que ofrece programación dirigida al público en general o a una parte de él, que consiste en la emisión, transmisión, difusión, distribución, radiación y recepción de señales de audio y video en forma simultánea. Dicho servicio como ya lo expresamos se encuentra reglado y definido en su clasificación en razón a diferentes factores que no es del caso volver a mencionar; salvo en lo que concierne a enfatizar que para el caso concreto en estudio debemos tener en cuenta que nos referimos a:

a) Televisión radiodifundida, entendida como aquella en la que la señal de televisión llega al usuario desde la estación transmisora por medio del espectro electromagnético, propagándose sin guía artificial.

b) Televisión abierta dado que la señal puede ser recibida libremente por cualquier persona ubicada en el área de servicio.

c) Televisión con nivel de cubrimiento nacional, debe cubrir todo el territorio Colombiano.

d) Televisión abierta nacional de operación privada, definida como aquella autorizada como alternativa privada y abierta al público para cubrir de manera permanente las necesidades del servicio y la prestación eficiente y competitiva del mismo en todo el territorio nacional.

Por definición legal, el derecho de operar y explotar medios masivos de televisión debe ser autorizado por el Estado, y depender de las posibilidades del espectro electromagnético, de las necesidades del servicio y de la prestación eficiente y competitiva del mismo; y que se consideran operadores para el caso concreto, las personas jurídicas privadas, con ánimo de lucro, que utilizan directamente las frecuencias requeridas para la prestación del servicio público de televisión en virtud de un título concedido por ministerio de la Ley, por un contrato. Y a su vez esos concesionarios privados tienen autorización legal para contar con inversión extranjera hasta en el cuarenta por ciento (40\%) del total del capital social del concesionario.(1995).

Ahora bien, debemos tener claro que la competencia referida a los operadores, no solo es referida a la adjudicación de la concesión para la prestación del servicio público sino la asignación de las frecuencias para el uso del espectro atribuidas al servicio de televisión, las cuales deben estar definidas, antes del inicio del proceso de selección, debemos tener claro que habrá de acudirse por obligación a la aplicación concurrente de lo determinado por la Ley 182 en su artículo 48 (art. 23 de la Ley 335 de $1996^{34}$ ) en cuanto al procedimiento para la selección de concesionarios de los operadores nacionales y lo establecido en el artículo 72 de la Ley 1341 en cuanto define textualmente:

Reglas para los procesos de asignación de espectro con pluralidad de interesados ${ }^{\mathbf{3 5}}$. Con el fin de asegurar procesos transparentes en la asignación de bandas de frecuencia y la maximización de recursos para el Estado, todas las entidades a cargo de la administración

34Cuando quiera que se encuentre en su texto la expresión 'Canal Zonal o Canales Zonales', entiéndase que se trata de Canales Nacionales de Operación Privada. Igualmente cuando la Ley se refiera a canales nacionales, deberá entenderse que se trata de los Canales Nacionales de Operación Pública, esto es, los que están constituidos por los concesionarios de espacios de televisión.

35 Reglamentado por el Decreto Nacional 4392 de 2010 
del espectro radioeléctrico incluyendo al Ministerio de Tecnologías de la Información y las Comunicaciones, la Comisión Nacional de Televisión, deberán someterse a las siguientes reglas:

Previamente al proceso de otorgamiento del permiso de uso del espectro radioeléctrico de asignación o de concesión de servicios que incluya una banda de frecuencias, se determinará si existe un número plural de interesados en la banda de frecuencias correspondiente.

En caso de que exista un número plural de interesados en dicha banda, y con el fin de maximizar los recursos para el Fondo de Tecnologías de la Información y las Comunicaciones y el Fondo para el Desarrollo de la Televisión, se aplicarán procesos de selección objetiva entre ellos la subasta. (Subrayado y resaltado fuera del texto) (2009)

Esta disposición implica como exigencias concurrentes para poder asignar las bandas de frecuencia para uso del servicio público de televisión y en general para los servicios de Tic, las siguientes connotaciones de obligatorio cumplimiento, así:

i. La existencia de un numero plural de interesados en el uso de las bandas de frecuencia.

ii. Maximización de recursos a través de subasta a la alza, esto es a quien ofrezca el mayor precio por ese derecho de uso; u otro mecanismo que lo garantice.

La pluralidad se contextualiza, en la existencia del Registro Único de Operadores del Servicio de Televisión -RUO-, la cual se fundamenta en el agotamiento de un proceso de inscripción, calificación y clasificación de los operadores que aspiran celebrar contratos de concesión para la prestación del servicio de televisión.

Vale la pena puntualizar que el Estatuto General de Contratación Pública, estipula que para efectos de que las entidades del Estado puedan proceder a verificar las condiciones de los proponentes dentro de los procesos de selección de contratista que se adelanten, lo deben hacer únicamente obre el Registro Único de Proveedores -RUP-, y para tal efecto consagra que todas las personas naturales o jurídicas nacionales o extranjeras domiciliadas o con sucursal en Colombia, que aspiren a celebrar contratos con las entidades estatales, se inscribirán en el Registro único de Proponentes del Registro Único Empresarial de la Cámara de Comercio con jurisdicción en su domicilio principal. (art. 6 de la Ley 1150); y consagra algunas excepciones de manera taxativa, dentro de las cuales se encuentra los contratos del tema que nos ocupa, así "No se requerirá de este registro, ni de calificación ni de clasificación, en los casos de (...) los contratos de concesión de cualquier índole.(...) corresponderá a las entidades contratantes cumplir con la labor de verificación de las condiciones de los proponentes". (subrayado fuera del texto) (2007).

Es así como, para verificar las condiciones que deben reunir los proponentes dentro de un proceso de selección de contratistas para la adjudicación de las bandas de frecuencia atribuidas a la prestación del servicio de televisión abierta nacional por parte de operadores privados, el trámite que los interesados deben surtir es la inscripción en el Registro Único de OperadoresRUO- (Coordinación de Normatividad, Protección y Promocion ANTV, 2012, 2-42)

La ANTV al proceder a generar la reglamentación del RUO del Servicio de Televisión, ha tenido en consideración diferentes aspectos que es del caso entrar a mencionar, en cuanto para el efecto generaron una actividad de análisis del mercado de televisión abierta, a través de mecanismo de participación de preguntas y respuestas, análisis del sector, y verificación de las 
experiencias fallidas de adjudicación de un tercer canal de televisión abierta con cubrimiento nacional.

Es el artículo 48 de la Ley 182 la que genera de denominación de Registro Único de Operadores, refiriéndola al otorgamiento de concesiones para operadores de televisión abierta nacional e impone la obligación de estar inscritos, calificados y clasificados a quienes aspiren a participar en el proceso de selección de contratista ${ }^{36}$.

La modificación generada en el año 2012 frente al registro buscó ajustarlo a las condiciones del mercado, a la normatividad y a los postulados del Acuerdo Comercial (Tratado de Libre Comercio - TLC-) suscrito entre la República de Colombia y los Estados Unidos de América. Así mismo, unificar y generar requisitos comunes tanto para concesionarios de espacios como de canales; constituyendo ese acto de registro una primera etapa de evaluación que se surte de manera previa a la apertura del proceso de selección del concesionario, otorgándole una vigencia a ese acto de registro de $\operatorname{dos}(2)$ años.

La connotación referida a la existencia de pluralidad de interesados, implica el que se cuente desde el inicio y hasta el final del procedimiento, con el interés y la participación de más de un operador inscrito, calificado y clasificado con anterioridad a la apertura de la licitación en el RUO etapa en la que la autoridad evaluara a cada operador su estructura organizacional, capacidad financiera y técnica, los equipos de que disponga, su experiencia y la de sus socios mayoritarios o con capacidad de decisión en los aspectos fundamentales de la compañía y esos elementos que se evalúan en esta etapa previa no podrán ser materia de nuevas evaluaciones durante el proceso licitatorio. Es así como esos inscritos se tienen como potenciales proponentes o interesados en participar en una licitación con el fin de ser concesionarios, pero su inscripción en el RUO no significa la expresión de interés de participación en la licitación misma.

Ya dentro de la licitación misma se pueden evaluar aspectos diferentes a los evaluados y calificados como por ejemplo la capacidad de inversión para desarrollo del mismo, la capacidad de cubrir áreas no servidas, el número de horas de programación ofrecida, mayor número de horas de programación nacional y la viabilidad económica de programación del servicio, entre otros y en todo caso por quien demuestre de manera satisfactoria una capacidad económica suficiente para cumplir con el plan de inversión correspondiente (1995).

Vale la pena puntualizar que la reglamentación del RUO del Servicio de Televisión, de que tratan los artículos 48 y 49 de la Ley 182 y $10^{\circ}$ de la Ley 335, se estructuró e implementó durante el año 2012 mediante resolución 0202 emitida por la ANTV, con el propósito de cumplir con los fines legales establecidos en las normas referidas; igualmente en aras de contribuir efectivamente en el desarrollo del proyecto regulatorio "Apertura del Mercado de la Televisión Abierta y Entrada de Nueva Oferta Televisa", formulado por la Autoridad nacional de Televisión - ANTV. como política gubernamental frente al servicio. (ANTV, 2012, P. 2-11).

La anterior reglamentación debe conjugar como ya lo expresamos con las exigencias o reglas para los procesos de asignación del espectro, en las cuales el legislador dispone que con el fin de (i) asegurar procesos transparentes en la asignación de bandas de frecuencia que garanticen la

36 CNTV Acuerdos 49 de 1998, 1, 2 y 3 de 1999, el Acuerdo CNTV 004 de 2003, el Acuerdo 4 de 2006 y el numeral 4 del artículo 30 del Acuerdo 10 de 2006, reglamentaban el RUO para los operadores de televisión por suscripción fueron derogados por la Resolución ANTV 033 de 2012. 
pluralidad y (ii) la maximización de recursos para el Estado, todas las entidades a cargo de la administración del espectro radioeléctrico incluyendo al Ministerio de Tic y a la ANTV, deberán someterse a ellas.

De lo anterior se colige que estas últimas reglas aplicables al proceso en estudio, implican una mayor complejidad, ya que exigen que además de existir varios inscritos en el RUO, estos deben expresar su interés de proponer y presentar ofertas manteniéndose hasta el final del procedimiento de licitación para que a través de una puja entre competidores (mínimo dos) y por el mecanismo de subasta se obtenga la propuesta más favorable que implica la asignación de esas frecuencias para el servicio de televisión; es decir que, de no existir esa pluralidad sería imposible la asignación. ${ }^{37}$

El artículo 72 de la Ley 1341 de 2009 contiene disposiciones de carácter especial a través de las cuales con sujeción a principios constitucionales, se establecen reglas imperativas, precisas y claras, configuradoras de los procesos administrativos de asignación del espectro electromagnético -bandas de frecuencia, espectro radioeléctrico-, transparentes y pluralistas, que tienen por finalidad la maximización de los recursos públicos, esto a través de la competencia que se genera a partir de una amplia participación de todos los actores del mercado interesados en el acceso al mismo (Zambrano Cetina, 2013).

Estos principios son entre otros; (i) la libre competencia,(ii) concurrencia ${ }^{38}$, (iii) pluralismo democrático participativo y (iv) transparencia- igualdad y no discriminación, lo que se refleja de manera indiscutible en la regla de procedibilidad del inciso segundo de la disposición, al exigir la verificación o determinación de la existencia de una pluralidad de interesados en la banda o frecuencia correspondiente, para iniciar válidamente cualquier proceso de selección de contratista de esta naturaleza"; tendiendo a evitar inexistencia de pluralismo participativo, en el interés que frente a la explotación y operación de un bien del estado como lo es el espectro electromagnético, en especial, cuando de por medio está la asignación de un servicio público de absoluto interés público, como lo es el de la televisión de operación privada y de cubrimiento nacional, que por su misma naturaleza y magnitud, deben estar dentro del marco del Estado social y democrático de derecho, y de la libre competencia económica (2013).

\section{Marco Jurídico de la Libre Competencia orientado a la prestación del servicio público de televisión.}

En desarrollo del marco jurídico constitucional referido a la libre competencia, al que ya hemos hecho referencia en el literal d, numeral $1.1 \mathrm{y}$ competencias del numeral 1.4 el presente trabajo podemos indicar, concretamente que de manera general, el marco de la libre competencia tiene un desarrollo amplio de acuerdo con el sector de servicios a los que se aplican sean domiciliarios

37 CALLE CORREA, María Victoria Sentencia C-403-10 Los artículos 11 y 72 de la Ley 1341 de 2009 tienen rasgos comunes: introducen una regla general en donde se señala que se adjudicarán los permisos en la utilización del espectro radioeléctrico mediante un mecanismo de selección objetiva, y a la vez establecen circunstancias excepcionales que autorizan la asignación directa de los permisos de uso del espectro radioeléctrico. Dos de las circunstancias excepcionales son comunes a ambas normas: (i) cuando prime la continuidad del servicio y (ii) cuando prime la ampliación de la cobertura. El artículo 11 establece una circunstancia adicional bajo la cual es posible exonerarse del procedimiento de selección objetiva y hacer la asignación de la banda de manera directa: cuando lo permitan (iii) la suficiencia del recurso y el nivel de ocupación de la banda. Por su parte, el artículo 72 autoriza la asignación directa de la banda cuando hay pluralidad de interesados, (iv) cuando prime el interés general.Bogotá.2010.

38 artículos 88 y 333 constitucionales, y recogidos en el artículo 2, numeral 2, de la misma Ley 1341 
o no domiciliarios, y de acuerdo con el régimen jurídico aplicable; que en el caso concreto que nos ocupa nos centra a considerar las normas de rango constitucional, y las legales específicas al tema del espectro electromagnético con asignación al servicio público de televisión, con consagración en las Leyes 1341 y 1507.

Ahora bien, el servicio público de televisión prestado por concesionarios de carácter privado, tiene un desarrollo práctico desde el año 1997 cuando fueron adjudicadas las primeras concesiones a los que hoy conocemos comúnmente como canales RCN y CARACOL. Es en torno a este tipo de servicio público que nos centraremos en desarrollo de este trabajo académico, habida cuenta de la necesidad del Gobierno Nacional de generar competencia de mercado frente a estos dos operadores incumbentes del servicio. Ese desarrollo práctico al que se hace referencia, se ha materializado en vigencia de la Constitución Política de 1991, el régimen especial vigente contenido en las Leyes 182, 335, 506,y 680; y las prórrogas de las concesiones bajo el marco normativo actualizado contemplado en las Leyes 1341 y 1507.

Como se expresó, deviene del artículo 75 de la Constitución Nacional la libre competencia frente a los servicio público de televisión; al dejar en cabeza del Estado plasmar la legislación que impida prácticas monopolísticas en el uso del espectro electromagnético; orientado a evitar el abuso de posiciones dominantes del mercado ${ }^{39}$, al contemplar textualmente:

El espectro electromagnético es un bien público inenajenable e imprescriptible sujeto a la gestión y control del Estado. Se garantiza la igualdad de oportunidades en el acceso a su uso en los términos que fije la Ley.

Para garantizar el pluralismo informativo y la competencia, el Estado intervendrá por mandato de la Ley para evitar las prácticas monopolísticas en el uso del espectro electromagnético." (subrayado fuera del texto) (Miranda Londoño, Abuso de la Posición Dominante.Perspectivas de la Aplicación en Colombia a la luz del Derecho Comparado, 1997).

A su vez la Carta Política consagra como lo vimos, en su artículo 333, que igualmente utilizando la Ley como instrumento el Estado impedirá o evitara que la libertad económica sea restringida y los abusos que frente al tema se presenten; y en su artículo $365^{40}$, que hace parte del capítulo $\mathrm{V}$ respecto a la finalidad social del Estado y de los Servicios Públicos, determina que estos últimos son inherentes a la finalidad del primero, y que en consecuencia debe asegurarse de su prestación eficiente, sometidos al régimen legal.

La Ley especial que rige el sector de Tic, al establecer su marco general ddetermina que el servicio de televisión continuará rigiéndose por las normas especiales pertinentes, indica que ello se materializa sin perjuicio de la aplicación de los principios generales del derecho. La norma ibídem a la vez determina que las Tic deben servir al interés general y es deber del Estado promover su acceso eficiente y en igualdad de oportunidades, a todos los habitantes, y determina taxativamente los siguientes principios orientadores: como pilares orientados a garantizar entre

39 MIRANDA, Londoño Alfonso, Abuso de la Posición Dominante: Perspectivas de la aplicación en Colombia a la luz del Derecho Comparado". Publicado en Seminarios 5 Universidad Javeriana. Centro de estudios de Derecho de la Competencia” 2 Edición, 1997. Página 21 y s.s.

40. Los servicios públicos son inherentes a la finalidad social del Estado. Es deber del Estado asegurar su prestación eficiente a todos los habitantes del territorio nacional. Los servicios públicos estarán sometidos al régimen jurídico que fije la Ley, podrán ser prestados por el Estado, directa o indirectamente, por comunidades organizadas, o por particulares. En todo caso, el Estado mantendrá la regulación, el control y la vigilancia de dichos servicios. Si por razones de soberanía o de interés social, el Estado, mediante Ley aprobada por la mayoría de los miembros de una y otra cámara, por iniciativa del Gobierno decide reservarse determinadas actividades estratégicas o servicios públicos, deberá indemnizar previa y plenamente a las personas que en virtud de dicha Ley, queden privadas del ejercicio de una actividad lícita. 
otros aspectos, el marco legal general de la libre competencia respecto al servicio público de televisión que implica el uso del espectro electromagnético, así:

1) Prioridad al acceso y uso de las Tecnologías de la Información y las Comunicaciones.

2) Libre competencia

3) Uso eficiente de la infraestructura y de los recursos escasos.

4) Protección de los derechos de los usuarios.

5) Promoción de la Inversión.

6) Neutralidad Tecnológica.

7) El derecho a la comunicación, la información y la educación y los servicios básicos.

8) Masificación del Gobierno en Línea.

Para el tema que nos ocupa, no solo por ser elemento esencial del problema juridico planteado, sino por su incidencia en la aplicación armónica de las disposiciones que conciernen a su materialización, se destaca para efectos de dar clara aplicación del artículo 72 de la Ley, entramos a analizar el principio relativo a la promoción de la libre y leal competencia, el cual en el numeral segundo del artículo segundo de la Ley 1341, está concebido textualmente como se transcribe a continuación:

Principios orientadores.(...) 2. Libre competencia: El Estado propiciará escenarios de libre y leal competencia que incentiven la inversión actual y futura en el sector de las TIC y que permitan la concurrencia al mercado, con observancia del régimen de competencia, bajo precios de mercado y en condiciones de igualdad. Sin perjuicio de lo anterior, el Estado no podrá fijar condiciones distintas ni privilegios a favor de unos competidores en situaciones similares a las de otros y propiciará la sana competencia."(Resaltado fuera del texto)

La Ley 1341, consagra el marco general con base en el cual se podrán generar las políticas públicas del sector, y además de que invoca la aplicación de los principios generales del derecho, consagra en forma especial los ya relacionados en la búsqueda de que los operadores de los servicios de tic colaboren dando prioridad a lo esencial que es la prestación de cada servicio que brinden en condiciones no discriminatorias de competitividad ${ }^{41}$, garantizando igualdad de oportunidades de acceso al uso del espectro electromagnético ${ }^{42}$, promoción de la inversión que va ligada de la mano a la garantía de uso de cualquier tipo de tecnología ${ }^{43}$, así como a que dichos pilares se enfoquen a garantizar el acceso a los servicios en igualdad de condiciones a todos los habitantes del territorio nacional para efectos de mejoramiento de la calidad de vida en educación, oportunidades laborales salud, emprendimiento, el derecho a la información, etc. ${ }^{44}$

41. Prioridad al acceso y uso de las Tecnologías de la Información y las Comunicaciones. El Estado y en general todos los agentes del sector de las Tecnologías de la Información y las Comunicaciones deberán colaborar, dentro del marco de sus obligaciones, para priorizar el acceso y uso a las Tecnologías de la Información y las Comunicaciones en la producción de bienes y servicios, en condiciones no discriminatorias en la conectividad, la educación, los contenidos y la competitividad.

42 Promoción de la Inversión. Todos los proveedores de redes y servicios de telecomunicaciones tendrán igualdad de oportunidades para acceder al uso del espectro y contribuirán al Fondo de Tecnologías de la Información y las Comunicaciones.

43. Neutralidad Tecnológica. El Estado garantizará la libre adopción de tecnologías, teniendo en cuenta recomendaciones, conceptos y normativas de los organismos internacionales competentes e idóneos en la materia, que permitan fomentar la eficiente prestación de servicios, contenidos y aplicaciones que usen Tecnologías de la Información y las Comunicaciones y garantizar la libre y leal competencia, y que su adopción sea armónica con el desarrollo ambiental sostenible.

44 El derecho a la comunicación, la información y la educación y los servicios básicos de las TIC. En desarrollo de los artículos 20 y 67 de la Constitución Nacional el Estado propiciará a todo colombiano el derecho al acceso a las tecnologías de la información y las comunicaciones básicas, que permitan el ejercicio pleno de los siguientes derechos: La libertad de expresión y de difundir su pensamiento y opiniones, la de informar y recibir información veraz e imparcial, la educación y el acceso al conocimiento, a la ciencia, a la técnica, y a los demás bienes y valores de la cultura. Adicionalmente el Estado establecerá programas para que la población de los estratos <sic> desarrollará programas para que la población de los estratos menos favorecidos y la población rural tengan acceso y uso a las plataformas de comunicación, en especial de Internet y contenidos informáticos y de educación integral. 
Claramente en este trabajo académico no nos referimos a la competencia que se materializa entre los operadores y actuales prestatarios del servicio de televisión, ni la referida a la satisfacción de las necesidades, requerimientos del televidente como consumidor del servicio público de televisión, sino netamente orientada a la garantía constitucional y legal de que puedan entrar al mercado del servicio público de televisión operadores privados nuevos o diferentes a los incumbentes o que actualmente brindan el servicio; de lo contrario nos saldríamos del contexto del tema propuesto. Así las cosas el marco legal de competencia leal está circunscrito a las normas constitucionales ya esbozadas y a las referidas en este acápite en torno a la correcta aplicación del artículo 72 de la Ley 1341.

Desde el punto de vista de la competencia es la Comisión de Regulación de Comunicaciones CRC, de que tratan las Leyes 142 de 1994 y 1341 de 2009, la encargada de promover la competencia, evitar el abuso de posición dominante y regular los mercados de las redes y los servicios de comunicaciones a través de la generación de la regulación que incentive la competencia de mercado basada en los principios y pilares orientadores de la Ley; con el fin que la prestación de los servicios sea económicamente eficiente, y refleje los niveles de calidad para los cuales están determinados legalmente.

Dentro de sus funciones están incluidas las inherentes a la promoción de la práctica de leal competencia y prevención de los actos desleales y restrictivos; resolviendo dentro de su marco de competencia potenciales controversias entre los proveedores de los servicios de tic; pudiendo imponer de oficio o a solicitud de interesados medidas que garanticen la interoperabilidad de los servicios de tic.

En desarrollo de su agenda de gestión, la Comisión de Regulación de Comunicaciones desarrollo sesiones y mesas de trabajo e intervención que se materializan en un documento denominado -Simplificación normativa para promover la competencia y la inversión-, el cual tiene como objetivo fundamental el que el sector de tecnologías de la información en general, incluido el servicio público de televisión participara en la revisión de la regulación existente y se propendiera por generar el mapa de necesidades que confluyeran en la reducción de las normas y reglamentaciones vigentes enfocadas a trámites, los cuales se irán desarrollando y consolidado de manera progresiva; y cuyos resultados al momento no es palpable determinarlos, no solo por ser un trabajo reciente dado que se publicó el 20 de agosto de 2015, pese a estar actualizado desde el mes de julio; sino porque se desarrolla de manera progresiva por cada tipo de servicio de los que regula dentro del sector. En dicho documento la orientación se enfocó en mayor grado a la televisión por suscripción y la concepción de los particulares frente al servicio público, sin adentrarse al régimen específico de competencia del que trata este análisis. (Coordinación de Regulación, Relaciones de Gobierno y Asesoría CRC, 2015, p. 1-23)

Pasamos a hacer una breve evocación jurisprudencial, citando por ejemplo la concepción que ha hecho el Honorable Consejo de Estado, en aplicación del principio de la libre competencia en un estado social de derecho, esta determinó:

observa la Sala que uno de los principios de la contratación estatal es el de libre la concurrencia o competencia, que deriva su existencia de los pilares sobre los cuales descansa el modelo económico del Estado adoptado por la Constitución Política, es decir, la propiedad 
privada, la libertad de empresa, la libre competencia económica (artículo 333 de la C.P.) ${ }^{45}$ y la función social y ecológica de la propiedad, así como de los principios de igualdad, imparcialidad, transparencia, publicidad y economía, que también son principios fundamentales de la contratación pública.

El principio la libre concurrencia implica la libertad de competir en condiciones de igualdad por parte de los sujetos interesados en realizar determinada actividad económica, y “(...)deviene del alcance material y sistemático surgido de la interacción entre las cláusulas constitucionales de la libre competencia instituida en los artículos 88 [que lo define como derecho colectivo] y 333 constitucionales y la del Estado social y democrático de derecho, que hacen del concepto, no solo uno de los pilares de la constitución económica ${ }^{46}$, en cuanto soporta a oferentes y demandantes de bienes y servicios en la dinámica del mercado, sino también, que lo torna en un concepto materialmente vinculado a los elementos propios de la vida democrática de nuestra sociedad ${ }^{47}$, vinculado con el interés general, esto es de carácter colectivo, sin perder su horizonte como derecho subjetivo (Consejo de Estado, 2012, p 2$15) .^{48}$.

Igualmente ha precisado el Honorable Consejo de Estado, que

La libre competencia económica implica necesariamente para un bien o servicio determinado, que existe una pluralidad de oferentes y una pluralidad de demandantes, en donde quienes ofrecen compiten entre sí para que los consumidores los elijan, y los consumidores, a su vez, entre ellos, para tener la posibilidad de adquirir los bienes o servicios requeridos, dado que en el mercado la oferta es siempre limitada. ${ }^{49}$ (...)"

La libre competencia económica se concreta en las exigencias establecidas por la Ley 1341 en su artículo 72, al ser concomitantes e indisolubles, en cuanto a deben coincidir la pluralidad de interesados y la maximización de recursos; y se debe en consecuencia propender por generar procesos que evidencien:

a. Libre concurrencia plural de interesados al mercado.

45. La actividad económica y la iniciativa privada son libres, dentro de los límites del bien común. Nadie podrá exigir permisos previos ni requisitos, sin autorización de la Ley. La libre competencia es un derecho de todos que supone responsabilidades. La empresa, como base del desarrollo, tiene una función social que implica obligaciones. El Estado fortalecerá las organizaciones solidarias y estimulará el desarrollo empresarial. El Estado, por mandato de la Ley, impedirá que se obstruya o se restrinja la libertad económica y evitará o controlará cualquier abuso que personas o empresas hagan de su posición dominante en el mercado nacional.

La Ley delimitará el alcance de la libertad económica cuando así lo exijan el interés social, el ambiente y el patrimonio cultural de la nación."

46 “[23]PALACIOS MEJÍA, Hugo. 'El derecho de los servicios públicos, Derecho Vigente'. Bogotá, 1999, Págs. 44 a 46”.

47 CORTE CONSTITUCIONAL.. La libertad de empresa y la libre competencia económica son dos garantías cardinales de la llamada 'constitución económica' que se erigen en fundamento del desarrollo económico y social así como en garantía de una sociedad democrática y pluralista". Bogotá, 2003.

48 CORTE CONSTITUCIONAL. Se reconoce y garantiza la libre competencia económica como expresión de la libre iniciativa privada en aras de obtener un beneficio o ganancia por el desarrollo y explotación de una actividad económica. No obstante, los cánones y mandatos del Estado Social imponen la obligación de armonizar dicha libertad con la función social que le es propia, es decir, es obligación de los empresarios estarse al fin social y a los límites del bien común que acompañan el ejercicio de la citada libertad. Bajo estas consideraciones se concibe a la libre competencia económica, como un derecho individual y a la vez colectivo, cuya finalidad es alcanzar un estado de competencia real, libre y no falseada, que permita la obtención del lucro individual para el empresario, a la vez que genera beneficios para el consumidor con bienes y servicios de mejor calidad, con mayores garantías y a un precio real y justo. Por lo tanto, el Estado bajo una concepción social del mercado, no actúa sólo como garante de los derechos económicos individuales, sino como corrector de las desigualdades sociales que se derivan del ejercicio irregular o arbitrario de tales libertades...Bogotá.2001.

49CORTE CONSTITUCIONAL La protección a la libre competencia económica tiene también como objeto, la competencia en sí misma considerada, es decir, más allá de salvaguardar la relación o tensión entre competidores, debe impulsar o promover la existencia de una pluralidad de oferentes que hagan efectivo el derecho a la libre elección de los consumidores, y le permita al Estado evitar la conformación de monopolios, las prácticas restrictivas de la competencia o eventuales abusos de posiciones dominantes que produzcan distorsiones en el sistema económico competitivo. Así se garantiza tanto el interés de los competidores, el colectivo de los consumidores y el interés público del Estado...” (Subrayado y resaltado nuestro y fuera del texto). Bogotá,2001. 
b. Conformación dinámica de los precios

c. Igualdad y no discriminación en el acceso al espectro electromagnético, esto es, sin privilegios a favor de uno o algunos de los competidores

d. Transparencia, y

e. Selección objetiva.

En el sentir del profesor José Antonio Moreno Molina, "el principio de libre concurrencia plural de interesados al mercado, busca hacer énfasis y determinar los procesos de contratación pública bajo senderos de competencia real con el fin de obtener a través de la presencia plural de oferentes interesados interactuando, una oferta adecuada" (Moreno Molina, 2006, p. 47.)

Las bases del Plan de Desarrollo de 2011, contemplaban de manera expresa

Aspectos regulatorios a pesar de la expedición de la Ley de Competencia y de la definición de la SIC como Autoridad Nacional de Competencia, sigue existiendo alguna dispersión en la legislación referente al régimen de competencia aplicable en Colombia, lo que genera confusiones en los agentes económicos y dificulta su aplicación. Los inconvenientes causados por este tipo de circunstancias se hacen evidentes en sectores donde hay empaquetamiento de servicios y múltiples autoridades de vigilancia y control -por ejemplo, en los mercados de telefonía, televisión e Internet-, que han sufrido una reconversión tecnológica hacia un sector integrado de telecomunicaciones. De acuerdo con la OECD y el BID (óp. cit.), las disposiciones de la legislación nacional en relación con la prohibición del abuso de posición dominante y el control de integraciones empresariales están acordes con las prácticas internacionales. No obstante, por considerarse de especial interés para la economía, la facultad para la evaluación y aprobación de proyectos de integración o reorganización empresarial está delegada en la Superintendencia Financiera de Colombia (Ley 1340 de 2009, artículo 8 parágrafo y artículo 9), para las operaciones en las que participen exclusivamente empresas vigiladas por esta entidad.(...) (Resaltado fuera del texto)

En el actual plan de desarrollo, se consagra la libre competencia como un eje que debe impulsarse y promoverse en todos los sectores, sin que haga manifestación adicional a la que corresponde a cada uno de ellos.

La Corte Constitucional, mediante sentencia C-815 de $2001^{50}$, sobre la doble dimensión que adquiere el interés general cuando se garantiza la libre competencia, y con fundamento en lo cual declaró la inexequibilidad de la expresión el interés general contenida en el último inciso del artículo 72 de la Ley 1341, señaló:

Por ello, la protección a la libre competencia económica tiene también como objeto, la competencia en sí misma considerada, es decir, más allá de salvaguardar la relación o tensión entre competidores, debe impulsar o promover la existencia de una pluralidad de oferentes que hagan efectivo el derecho a la libre elección de los consumidores, y le permita al Estado evitar la conformación de monopolios, las prácticas restrictivas de la competencia o eventuales abusos de posiciones dominantes que produzcan distorsiones en el sistema económico competitivo. Así se garantiza tanto el interés de los competidores, el colectivo de los consumidores y el interés público del Estado.

$50{ }^{1}$ MP. Rodrigo Escobar Gil. AV. Manuel José Cepeda Espinosa 
Ahora bien, en cuanto a la facultad para conocer los temas inherentes a la violación del principio de la libre competencia, debemos remitirnos a lo reglado por la Ley 1507 de 2012, en su artículo 13, en el cual se redistribuye una de las facultades que radicaban en cabeza de la liquidada CNTV, asignándoselas a la Superintendencia de Industria y Comercio, en el siguiente sentido:

Distribución de funciones en materia de prácticas restrictivas de la competencia e integraciones empresariales. La Superintendencia de Industria y Comercio de conformidad con lo previsto en la Ley 1340 de $2009^{51}$, seguirá conociendo de las funciones que el literal d) ${ }^{52}$ del artículo $5^{\circ}$ de la Ley 182 de 1995, y el artículo $2^{\circ}$ de la Ley 680 de 2001, le atribuían a la Comisión Nacional de Televisión."

\subsection{Tratamiento Jurisprudencial concretamente referido a la entrada en servicio de un nuevo operador privado del servicio público de televisión como manifestación de la libre competencia.}

Si bien en la relatoría jurisprudencial se encuentran amplios antecedentes frente a los mecanismos de selección objetiva, sus principios rectores, la aplicación de disposiciones a casos específicos, la evolución normativa, entre otros temas, en el presente componente nos limitaremos a presentar los pronunciamientos de las Altas Cortes y el Consejo de Estado orientados al tema específico de estudio, ya que en la medida en que se fue avanzando en la investigación académica se observa no solamente el que son puntuales las decisiones que en torno al uso del espectro para el servicio de televisión por parte de operadores privados se han generado, sino que también dichos pronunciamientos tuvieron origen en los intentos del Estado por la materialización de la libre competencia al acceso de nuevos agentes de mercado.

Es así que el servicio por parte de operadores privados con cubrimiento nacional se brinda desde el año 1997, y los intentos por ampliar el margen de competencia a la fecha han sido fallidos y han quedado materializados en diferentes manifestaciones de orden jurisprudencial, que analizaremos cronológicamente en su mención y transcripción de apartes; a efectos de contextualizarlos de forma más específica, a nivel histórico y cronológico, debemos mencionar los eventos puntuales, así:

a) La Licitación pública que dio origen a las actuales concesiones del servicio a través de operadores privados.

51 Normas en materia de protección de la competencia.

52 Investigar y sancionar a los operadores, concesionarios de espacios y contratistas de televisión por violación del régimen de protección de la competencia, el pluralismo informativo y del régimen para evitar las prácticas monopolísticas previsto en la Constitución y en la presente y en otras Leyes, o por incurrir en prácticas, actividades o arreglos que sean contrarios a la libre y leal competencia y a la igualdad de oportunidades entre aquéllos, o que tiendan a la concentración de la propiedad o del poder informativo en los servicios de televisión, o a la formación indebida de una posición dominante en el mercado, o que constituyan una especie de práctica monopolística en el uso del espectro electromagnético y en la prestación del servicio.

Las personas que infrinjan lo dispuesto en este literal serán sancionadas con multas individuales desde seiscientos (600) hasta seis mil (6.000) salarios mínimos legales mensuales vigentes a la fecha de la sanción, y deberán cesar en las prácticas o conductas que hayan originado la sanción. Igualmente, la Comisión sancionará con multa desde cien (100) hasta seiscientos (600) salarios mínimos legales mensuales vigentes a la fecha de la sanción a los administradores, directores, representantes legales, revisores fiscales y demás personas naturales que autoricen, ejecuten o toleren las conductas prohibidas por la Constitución y la Ley.

Para los fines de lo dispuesto en este literal, se atenderán las normas del debido proceso administrativo. Al expedir los Estatutos, la Junta Directiva de la Comisión creará una dependencia encargada exclusivamente del ejercicio de las presentes funciones. En todo caso, la Junta decidirá en segunda instancia 
En el año 1997, la CNTV hoy liquidada, adjudicó a Caracol Televisión S.A., y a RCN Televisión S.A., la concesión para la operación y explotación de dos canales de televisión de operación privada de cubrimiento nacional por un plazo inicial de diez años. (Miranda Londoño, El Derecho de la Competencia en el Servicio Público de Televisión, 2003, p.1-34)

\section{b) Los actos de prórroga de las actuales concesiones del servicio.}

Los actos de prórroga de los contratos de concesión 136 de 1997 y 140 de 1997, suscritos con Caracol Televisión S.A. y RCN Televisión S.A. (Revista Semana, 2008)

\section{c) La licitación Pública 001 de 2009.}

Con posterioridad se adelantó el proceso de licitación pública No. 001 de 2009, para la Concesión de la Operación y Explotación del Canal de Televisión de Operación Privada de Cubrimiento Nacional cuya apertura se ordenó mediante Resolución No. 1210 del 29 de octubre de 2009; y resolvió su revocatoria, mediante Resolución № 20103800000044 del 7 de enero de 2010 al considerar que la estructura del proceso no garantizaba habida cuenta de la evolución económica del sector, el uso adecuado y eficiente de los recursos públicos, al no plasmarse un modelo económico favorable para el Estado Colombiano. (Agencia Nacional de Contratación Pública, 2009)

\section{d) Licitación Pública 002 de 2010.}

La Comisión Nacional de televisión- CNTV- hoy liquidada, con el fin de dar cumplimiento a lo dispuesto por su propia Junta, mediante acta número 1350 del 09 de agosto de 2007, en cuanto generar las acciones tendientes a la existencia de un tercer canal de televisión de operación privada y cubrimiento nacional para Colombia, mediante Resolución 481 del 07 de mayo de 2010, dispuso la apertura a la Licitación Pública No. 002 de 2010, la cual fue posteriormente declarada desierta mediante Resolución 468 del 03 de abril de 2012, en acatamiento de lo juzgado por el Honorable Consejo de Estado en Sentencia del 14 de febrero de 2012, en virtud de la cual el alto Tribunal consideró que el hecho de que existiera un único proponente, afectaba la selección objetiva y por lo tanto no había lugar a adjudicar el contrato. ( Agencia Nacional de Contratación Pública, 2010)

\section{e) La Autoridad Nacional de Televisión y su Agenda Estratégica.}

La ANTV en ejercicio de atribuciones, concibió su Agenda Estratégica 2013; en la cual planteó una propuesta de Agenda Estratégica que incluía más oferta de canales y espacios de televisión, para lo cual contrataría la estructuración y valoración de los procesos licitatorios para otorgar las concesiones para la Operación Privada del Servicio Público de TV en el Nivel de Cubrimiento Nacional y las concesiones de Espacios de TV Revisión para la apertura a los mercados radiodifundidos locales (Actividades 2,3, 4, 5 y 6). Estudios que a la fecha no han posibilitado la adjudicación de nuevos canales de operación del servicio.(ANTV.Coordinación de Normatividad, Promoción y Protecccion, 2012)

Hecho lo anterior, debe considerarse que en el tema jurisprudencial confluyen aspectos inherentes al proceso de licitación pública propiamente concebida, esto es los pronunciamientos 
referidos a selección objetiva, libre concurrencia, y demás correlacionados a los mecanismos públicos de selección de contratista, pero en este análisis solo nos referiremos a los que han tenido injerencia al pronunciarse sobre el espectro electromagnético y el servicio público de televisión que prestan operadores privados en el ámbito nacional; y son aquellas que han sido generadas en virtud de los intentos a los que nos hemos referido, que son frente a las que surge la necesidad de puntualizar, en palabras propias y textuales de quienes definieron cada tema por parte de la autoridad que conoció el caso propuesto. (Consejo de Estado, 2001) Así:

\section{$1^{\circ}$ Conceptos de la Sala de Consulta y Servicio Civil del Honorable Consejo de Estado de fechas 05-10-2009 y 25-02-2010.}

El alcance y contenido de la decisión de la Sala de Consulta y Servicio Civil del Honorable Consejo de Estado, siendo Consejero Ponente el Magistrado Ponente Doctor William Zambrano Cetina, dentro del Expediente 11001-03-06-000-2009-00049-00, referidos a la pluralidad de oferentes en la adjudicación de un potencial tercer canal de televisión; concreto los siguientes aspectos que generaron la declaratoria de la licitación pública 001 de 2009. (Consejo de Estado, 2009)

Consideró que la concesión de canales de televisión debe surtirse a través del mecanismo de selección de contratista denominado Licitación Pública, por ser la regla general, siendo improcedente la contratación directa aun frente a la circunstancia de que sea un solo interesado en proponer el que se encuentre inscrito en el RUO; debiéndose exigir como presupuesto del procedimiento la concurrencia plural de interesados, previa convocatoria pública. En consecuencia el hecho de la existencia de un solo inscrito imposibilita el inicio de un procedimiento de selección de contratista que garantizara la libre competencia, que supone que el Estado cumple con la obligación de estructurar procesos que promuevan el acceso y participación los posibles interesados, así como la presentación del mayor número de ofertas posibles.

Frente a esta posición inicial el Ministerio Tic, solicito la ampliación del concepto 1966 de 2009, habiéndose respondido la consulta en los siguientes términos que nos permitimos referirnos de la manera más sucinta posible, así:

Ratifica el Honorable Consejo de Estado la necesidad de acudir a la Licitación Pública como único medio de selección que garantice la objetividad en la contratación del servicio público de televisión con asignación de espectro electromagnético. No compartiendo la visión del Ministerio en cuanto planteaba que el hecho de existir un solo inscrito en el RUO esto no afectaría el curso de una licitación pública, en cuanto seria como evadir la publicidad, la pluralidad, la libre concurrencia y las normas pasarían a ser requerimientos ignorados.

Se mantiene en que dicha pluralidad como exigencia de Ley debe sostenerse y mantenerse durante todo el proceso de selección y hasta el final del mismo., lo que obedece a poder hacer efectiva la materialización de la exigencia determinada por el legislador en el artículo 75 de la Ley 1341, respetándose los pilares de democratización del uso del espectro electromagnético que exige necesariamente la existencia de más de un proponente a efectos de obtener la maximización de recursos frente al precio base. Insistiendo en lo que se transcribe textualmente, así: 
Pero, si sólo existe un oferente y éste de antemano sabe que no habrá competencia (porque es el único inscrito en el RUO o porque los demás interesados se retiran del proceso contractual antes de vencerse el plazo para presentar ofertas), es claro que aquél no tendría ningún interés en hacer un ofrecimiento por encima del precio base o a lo sumo por ese valor más uno $(x+1)$, lo cual le bastaría para cumplir, formalmente, con la exigencia del pliego de condiciones de presentar una Oferta Económica para competir y ser elegido que sea superior al precio inicial propuesto por la CNTV; no obstante, es claro que en ese escenario se desvanecerían los propósitos del respectivo proceso contractual y se estaría renunciando por anticipado a una oferta real y efectiva por encima del precio base que se ha fijado. (Subrayado fuera del texto)

Llamó la atención el Honorable Consejo de Estado en advertir que no se estaba frente a un proceso de selección de contratista para asignar el uso de un bien y un servicio cualquiera, sino a unos debidamente regulados y reglamentados constitucional y legalmente, marco juridico que corresponde al mismo estado respetar y hacer efectivo en su cumplimiento.

\section{$2^{\circ}$ Decisión asumida por la Sala Plena de la Honorable Corte Constitucional mediante sentencia de fecha 27-05-2010 (Corte Constitucional, 2010).}

El alcance y contenido de la decisión de la Sala Plena de la Honorable Corte Constitucional, siendo MP María Victoria Calle Correa, dentro de la demanda de inconstitucionalidad contra los artículos 11 (parcial), 20 (parcial), 22-4 (parcial), 28 (parcial), 36, 68 y 72 (parcial) de la Ley 1341 de 2009, en la cual se determina en forma concluyente:

Los artículos 11 y 72 de la Ley 1341 de 2009 tienen rasgos comunes: introducen una regla general en donde se señala que se adjudicarán los permisos en la utilización del espectro radioeléctrico mediante un mecanismo de selección objetiva, y a la vez establecen circunstancias excepcionales que autorizan la asignación directa de los permisos de uso del espectro radioeléctrico. Dos de las circunstancias excepcionales son comunes a ambas normas: (i) cuando prime la continuidad del servicio y (ii) cuando prime la ampliación de la cobertura. El artículo 11 establece una circunstancia adicional bajo la cual es posible exonerarse del procedimiento de selección objetiva y hacer la asignación de la banda de manera directa: cuando lo permitan (iii) la suficiencia del recurso y el nivel de ocupación de la banda. Por su parte, el artículo 72 autoriza la asignación directa de la banda cuando hay pluralidad de interesados, (iv) cuando prime el interés general.

Los principales pronunciamientos que incumben al tema que nos ocupa, pasamos a mencionarlos de acuerdo con las expresiones textuales de la Honorable Corte Constitucional, omitiendo los no relevantes al tema, así:

- Consideraciones frente a las excepciones de adjudicación de una banda electromagnética.

Luego de generar el análisis de fundamentación constitucional y legal consideró que los elementos relevantes que ameritan la intervención del Estado al espectro electromagnético son su carácter de recurso limitado y su naturaleza de plataforma fundamental en el desarrollo de actividades informativas; manifestando que ello es correlativo y convergente con la necesidad de garantizar los principios de igualdad y libre competencia no pudiéndose generar la asignación 
por fuera del marco de legalidad de los recursos que soportan la prestación de los servicios de telecomunicaciones. Y contextualiza el tema expresando puntualmente que:

Si bien el recurso del que trata el artículo 75 de la Carta puede ser aprovechado por particulares, -en ejercicio de las libertades económicas que la misma Carta garantiza-, dicha facultad no está desprovista de límites. De hecho, se consagra la obligación de las autoridades públicas de evitar prácticas monopolísticas que minen valores fundamentales como el pluralismo informativo y la libertad de competencia -supuesto que también garantiza la Constitución en el artículo 333. Es así como se entiende que la disposición precitada no sólo protege la utilización del espectro electromagnético, sino que introduce en la ecuación constitucional el elemento de la igualdad y de la libre competencia, las cuales deberán ser tuteladas por el Estado mediante acciones positivas, tales como la promulgación de Leyes dirigidas a evitar la concentración de recursos en la utilización del espectro electromagnético por parte de uno o algunos particulares o las prácticas monopolísticas. (Subrayado fuera del texto)

Igualmente, refiere en su decisión sentencias tales como la C-083 de $1996^{53}$, C-815 de 2001 , en las cuales la Corte precisó que en la medida en que estamos frente a permisos para el uso de recursos limitados para la prestación de servicios de tecnologías, estos no pueden ser otorgados de forma desmedida y por ende la adjudicación de dichas frecuencias debe estar basada en los fines determinados por la Ley referidos a garantizar el libre acceso en condiciones de igualdad, y a evitar prácticas de posición dominante; determinando que si bien las normas demandadas contienen unos mecanismos de excepción estos tiene soporte en la potencialidad de presentarse la necesidad de evitar la paralización del servicio o la inexistencia en su prestación cuando esos motivos son ajenos a la voluntad del estado, primer evento excepcional es la adjudicación directa de la licencia o permiso para el uso del recurso escaso.

El segundo, tercero y cuarto eventos de excepción referidos a que prevalezca la necesidad de ampliación de la cobertura, a la primacía del interés general, a cuando el nivel de la ocupación de la banda y la suficiencia del recurso lo permitan, se consideraron inconstitucionales por ser contrarios a los principios de igualdad, pluralismo y la libre concurrencia, en beneficio de la generación de potenciales monopolios.

- Consideraciones frente a la contraprestación periódica a favor del Fondo de Tic no tiene carácter tributario.

En lo referente al tema consideró que la contraprestación en favor del Fondo de Tecnologías de la Información y las Comunicaciones es un precio público, sin carácter tributario, por la nominación misma de la norma que la consagra, no se paga indiscriminadamente sino solo por quienes tengan la condición de ser prestatarios del servicio específico, los dineros que se recauden por concepto de la contraprestación tienen como destino facilitar las funciones del FONDO y no son para uso indiscriminado

$3^{\circ}$ Decisión asumida por el Consejo de Estado mediante auto de fecha 14-02-2012. (2013)

53 (MP. Eduardo Cifuentes Muñoz) 
El alcance y contenido de la decisión del Honorable Consejo de Estado, emitida por la Sala plena de la Contencioso Administrativo, siendo Consejero Ponente el Doctor Jaime Orlando Santofimio Gamboa, dentro de la demanda instaurada contra la CNTV- hoy liquidada, en vía de acción de nulidad contra el acto administrativo que ordena la apertura de la licitación pública 002 de 2010, contenido en la Resolución 2010-380-000481-4 del 7 de mayo de 2010 y en los pliegos de condiciones, para la concesión de la operación y explotación de un tercer canal de televisión de operación privada de cubrimiento nacional. A continuación se analizan las consideración expuestas por la sala frente a cada componente objeto de análisis.

- Consideraciones frente a la naturaleza de los actos demandados.

Se ratifica en lo que la doctrina y Jurisprudencia han referido frente al tema, para concluir que en relación con el pliegos de condiciones, comporta la naturaleza de verdadero acto administrativo de carácter general de un acto administrativo precontractual de contenido general, es decir, una manifestación unilateral de la voluntad de la Administración que crea situaciones jurídicas generales, impersonales, abstractas y objetivas ${ }^{54}$, y en cuanto al acto de apertura, se le ha considerado por regla general como simple acto de trámite.

En cuanto a la consideración de que el Pliego de Condiciones, contravenga disposiciones de orden constitucional, legal o reglamentario, la misma corporación ha manifestado que:

un acto administrativo, que cuando contiene cláusulas violatorias de la Ley de contratación que restrinjan ilegalmente la participación de los oferentes o que de alguna manera se conviertan en un obstáculo para la selección objetiva, es posible demandarlo en acción o de nulidad o de nulidad y restablecimiento del derecho en defensa de la legalidad que debe presidir toda actuación administrativa, tal como lo establece el art. 87 del C.C.A con las modificaciones que le introdujo el art. 32 de la Ley 446 de 1998 "55.

Frente al acto de apertura de la licitación, la jurisprudencia ha sostenido que se trata de un acto de mero trámite $\mathrm{y}$, por tanto, en principio no podría ser impugnado autónomamente pues, por regla general, sólo serían demandables ante esta jurisdicción los actos definitivos, esto es, los que ponen fin a un procedimiento administrativo, o los actos que crean situaciones jurídicas; sin embargo la Sección Tercera ha clarificado que en algunas ocasiones resulta susceptible de ser enjuiciado, como cuando contiene decisiones sobre el fondo del asunto o que puedan afectar los principios que deben regir a la actividad contractual estatal. Ejemplo de ello es el auto de 6 de agosto de 1997, por medio del cual se admitió la demanda de nulidad simple contra el acto de apertura de una licitación, la Sala indicó:

Aunque en principio podría sostenerse que el acto de apertura de una licitación es de mero trámite, no siempre deberá mantenerse este calificativo, porque podrán darse casos en los que el acto, en lugar de limitarse a invitar a los interesados que estén en un mismo pie de igualdad para que participen en el proceso selectivo, restrinja indebida o ilegalmente esa

54 En este sentido véase entre otros pronunciamientos los siguientes: Consejo de Estado. Sección Tercera. Auto del 10 de octubre de 1991; Auto del 6 de noviembre de 1997; Sentencia del 19 de septiembre de 2007.

55 CONSEJO DE ESTADO, Exp: 15.235. CP Ricardo Hoyos Duque. Consultarse igualmente la sentencia del 11 de diciembre de 2003, Exp: 15.796. CP Ricardo Hoyos Duque.Bogotá,2004 
participación. Evento en el cual el acto así concebido podrá desconocer los principios de transparencia e igualdad de oportunidades y resultar afectado de desviación de poder. En otras palabras, ese acto deja de ser así un mero trámite para convertirse en un obstáculo para la selección objetiva de los contratistas.(...). En este sentido ya la jurisprudencia de la Sala ha aceptado la viabilidad de esta clase de acción frente a actos como los de apertura de una licitación o concurso y de adopción de pliegos de condiciones." 56 (Resaltado del texto original).

De acuerdo con lo hasta aquí expuesto, la Sala concluyó que las decisiones de la Administración contenidas en un acto de apertura de un proceso de selección de contratistas para el Estado, o en un Pliego de Condiciones son actos administrativos de contenido general; y como consecuencia de ello, podrían ser controvertibles judicialmente mediante la acción de nulidad.

- Consideraciones sobre el acceso al uso y explotación del espectro electromagnético.

La Ley de Tic- Ley 1341 y específicamente su artículo 72, fundada en consideraciones de libre competencia, concurrencia, pluralismo, democracia participativa y transparencia, y se ocupa de estructurar un conjunto de reglas aplicables a todos los procesos de naturaleza administrativa por parte de las entidades competentes para otorgar el uso y explotación del espectro electromagnético -bandas de frecuencia, espectro radioeléctrico-, bien público éste para el cual la Constitución Política establece especiales condiciones de acceso en su artículo 75 y que aquella disposición legal desarrolla.

Alcance:

a. Contiene disposiciones de carácter especial a través de las cuales y con sujeción a inobjetables principios de raigambre constitucional, se establecen reglas imperativas, precisas y claras, configuradoras de los procesos administrativos de asignación del espectro electromagnético bandas de frecuencia, espectro radioeléctrico-, transparentes y pluralistas

b. Su finalidad es obtener la maximización de los recursos públicos, esto a través de la competencia que se genera a partir de una amplia participación de todos los actores del mercado interesados en el acceso al mismo.

c. Es de la esencia misma de su configuración, el respeto y operatividad, de los principios constitucionales de la libre competencia, concurrencia, pluralismo democrático participativo y transparencia.

d. Es una regla de procedibilidad la verificación o determinación de la existencia de una pluralidad de interesados en la banda o frecuencia correspondiente, para iniciar válidamente cualquier proceso de selección de contratista de esta naturaleza.

e. Son requisitos tendientes a evitar procesos de selección carentes de la sustantividad pluralista y participativa necesaria en relación con un bien como lo es el espectro electromagnético, en especial, cuando de por medio está la asignación de un servicio público de absoluto interés público, como lo es el de la televisión de operación privada y de cubrimiento nacional.

- Consideraciones sobre el postulado constitucional de la libre competencia económica.

56 CONSEJO DE ESTADO. Exp: 13.495. CP Carlos Betancur Jaramillo.Bogotá.2004 
Se definió que debe existir una articulación armónica e integradora de contenidos normativos de carácter indisoluble, que vincula cualquier aproximación que se haga en relación con todas y cada una de las disposiciones de la Ley 1341 de 2009, determinando no solo su objeto, sino también, y de manera principal, el sendero teleológico de la misma, en cuanto que ordena que la finalidad de cada una de las disposiciones de la Ley, está dada a partir de su integración con los principios orientadores de la misma, entre ellos, y se destaca para efectos de una clara lectura del artículo 72 de la Ley, el de la promoción de la libre y leal competencia.

El concepto de libre y leal competencia económica deviene del alcance material y sistemático surgido de la interacción entre las cláusulas constitucionales de la libre competencia instituida en los artículos 88 y 333 constitucionales y la del Estado social y democrático de derecho, que hacen del concepto, no solo uno de los pilares de la constitución económica, en cuanto soporta a oferentes y demandantes de bienes y servicios en la dinámica del mercado.

La libre competencia económica implica necesariamente para un bien o servicio determinado, que existe una pluralidad de oferentes y una pluralidad de demandantes, en donde quienes ofrecen compiten entre sí para que los consumidores los elijan, y los consumidores, a su vez, entre ellos, para tener la posibilidad de adquirir los bienes o servicios requeridos, dado que en el mercado la oferta es siempre limitada. ${ }^{57}$

- $\quad$ Consideraciones sobre la selección objetiva del contratista.

Selección objetiva es la que no está inspirada en razones subjetivas, personales, viscerales de los servidores públicos, sino en consideraciones de colectividad, de interés general y de respuestas a necesidades evidentes de la comunidad. Tiene relación sustancial con el concepto de interés público o general. Puede decirse que constituye el más importante de sus instrumentos, constitutivo de requisito legal esencial respecto de la escogencia del contratista; esto es, norma imperativa de aplicación ineludible, y vinculante.

La escogencia objetiva en materia contractual significa abordar de manera concreta y efectiva, en todos los procedimientos de escogencia de contratistas principios como los de igualdad, participación y, en especial, el de la libre competencia económica. Lo anterior en virtud de que el deseo del legislador, al romper con los privilegios para la selección de un contratista, es el de permitir que todos aquellos sujetos del mercado que puedan proponerle a la administración bienes, servicios y demás objetos para atender sus necesidades lo hagan de acuerdo con las exigencias de los correspondientes pliegos, compitiendo bajo condiciones de igualdad de acuerdo con sus capacidades, experiencia y conocimientos, para que de esta manera puedan las entidades estatales identificar la propuesta que más favorezca a la entidad. (Bernal Pulido, Sf, p. 1-17)

Quiere el legislador que el principio en cuestión, se aplique por la administración en todo y cualquiera de los procedimientos de selección que adelante para darle cumplimiento a los propósitos y finalidades de la norma, sea subasta o cualquier otro, en todos ellos, sin distinción

57. CORTE CONSTITUCIONAL La protección a la libre competencia económica tiene también como objeto, la competencia en sí misma considerada, es decir, más allá de salvaguardar la relación o tensión entre competidores, debe impulsar o promover la existencia de una pluralidad de oferentes que hagan efectivo el derecho a la libre elección de los consumidores, y le permita al Estado evitar la conformación de monopolios, las prácticas restrictivas de la competencia o eventuales abusos de posiciones dominantes que produzcan distorsiones en el sistema económico competitivo. Así se garantiza tanto el interés de los competidores, el colectivo de los consumidores y el interés público del Estado.Bogotá.2001. 
alguna, deberán reinar de manera absoluta las consideraciones y variables objetivas y no las subjetivas para la selección de la mejor propuesta. Este es el alcance posible de la referencia a selección objetiva en la norma.

- Consideraciones para decidir sobre la nulidad de las disposiciones del pliego y el acto administrativo de apertura de la licitación 002 de 2010.

a. Desconocimiento absoluto del principio de la libre y leal competencia que conforma materialmente los contenidos normativos del artículo 72 de la Ley 1341 de 2009.

Consideran que las disposiciones del pliego al permitir y concebir la existencia de un oferente único y remitirse las normas generales de la contratación pública; violándose los preceptos de la norma especial la cual implica necesariamente y para todos los casos la presencia plural de interesados proponentes actuando de manera dinámica, esto es, compitiendo en torno a la configuración de una mejor propuesta para la entidad pública, en el caso particular, a través de la maximización del precio a ser pagado por el mejor postor en la subasta.

b. Desconocimiento absoluto del principio de la necesaria concurrencia de los actores del mercado interesados en acceder al espectro electromagnético y contratar con la administración pública la prestación del servicio de televisión privada y de cubrimiento nacional a través del mismo. Conforme lo establece el artículo 2, numeral 2 de la Ley 1341, al configurar la competencia necesariamente sobre la base de la pluralidad de concurrentes y no solo de un interesado o proponente, que para el caso es la misma cosa. La Ley está ordenando, y así se deduce de su simple lectura, el respeto a la pluralidad de interesados y no solo a la presencia de uno de ellos.

Lo que se quiere es que los actores del mercado, que no son otra cosa que personas que guardan un interés en el acceso y uso del espectro electromagnético para la prestación del servicio público de televisión, puedan materializar ese interés a través de propuestas y que a partir del interaccionar de las mismas se llegue a la mejor de ellas.

c. Desconocimiento absoluto del principio de la concurrencia y como consecuencia del mismo, la ruptura del postulado de la libre y leal competencia.

No es posible la competencia de un único interesado o proponente en una licitación en la cual se pretenda adjudicar bajo la modalidad de subasta, lo cual riñe manifiestamente con la realidad de los mandatos imperativos del artículo 72 de la Ley 1341 de 2009 interpretado a la luz de los artículos 2, numeral 2 y 7 de la misma, que para el caso concreto ordenan es una subasta competitiva, en cuanto mecanismo para la determinación del precio mediante el interaccionar de varios sujetos y no solo uno de ellos.

La figura del proponente único en la modalidad de subasta prevista en la norma rompe la columna vertebral estructuradora y de principios de la Ley 1341. Los procedimientos de selección a que se refiere el artículo 72, en especial la subasta al alza que es la que incorpora sin duda alguna el artículo en cuestión, es por su misma naturaleza plural y competida, lo cual no deja la posibilidad a la administración de diseñar una subasta que no se caracteriza conforme a estos postulados fundamentales de la Ley. 
d. Violación del principio de igualdad en materia de acceso y uso del espectro electromagnético ordenada en el artículo 75 constitucional y que es el objeto inmediato de las reglas establecidas en el artículo 72 de la Ley 1341 de 2009.

La igualdad implica respeto a la libre y leal competencia lo que no ocurre en el caso de la licitación 002 de 2010, en cuanto se parte de la negación a la competencia para instituir la hipótesis del proponente único habilitado. La igualdad se garantiza haciendo realmente efectiva la competencia en cuanto la misma se vincula a una pluralidad de actores del mercado interactuando, luego es en relación con el tratamiento que se le dé a cada uno de ellos en sus derechos, intereses, libertades y oportunidades, ligados con el conjunto y teniendo como referente objetivo el ordenamiento jurídico, que se consolida el derecho fundamental postulado en el principio en mención.

e. Imposibilidad de hacer la remisión a la normatividad general de la contratación de la administración.

La remisión que se hace en la norma demandada al artículo 90 del Decreto 2474 de 2008 reglamentario de la Ley 1150 de 2007, va más allá de las fronteras de la simple imprecisión; y pasa a ser una incontrovertible situación de ilegalidad; dadas las características y naturaleza de las hipótesis en él reguladas, no resulta de aplicación a la subasta ordenada por artículo 72 de la Ley 1341 de 2009, en cuanto su punto de partida es el de la subasta con un único proponente, luego trata un asunto incompatible con el desarrollado en la Ley especial que nos ocupa.

El artículo 72 de la Ley 1341 es una norma especial, que contiene situaciones especialmente referidas al acceso y uso del espectro electromagnético, de la postulación de reglas igualmente especiales soportadas en principios particulares derivados de la libre competencia económica, luego cualquier remisión normativa, de ser posible, solo se puede hacer manteniendo y preservando estos claros conceptos directores de la interpretación y de la hermenéutica jurídica.

f. Fijación del precio de la oferta económica por fuera de los marcos de la competencia.

El pliego de condiciones, viola los principios de conformación competida de precios y de selección objetiva establecidos en los artículos 72 y 2 , numeral 2 de la Ley 1341. La maximización de precios a que se refiere la base material de los procesos de selección establecida en la Ley 1341 de 2009, se desconoce abiertamente en la norma impugnada porque el precio real y definitivo a pagar por el actor del mercado interesado no surge de la competencia misma, para el caso de las pujas sucesivas al alza, sino del precio arbitrario y unilateral que claramente ha fijado la administración al estructurar el precepto, lo cual es totalmente contrario a las reglas del mercado y a los precios que deben emanar del mismo, según las previsiones imperativas del artículo 2, numeral 2 de la Ley 1341 de 2009.

La selección objetiva es resquebrajada ya que son dos las variables objetivas que no pueden de manera alguna faltar para efectos de la selección objetiva, en cualquier proceso de selección a que se refiere el artículo 72 los cuales ya hemos mencionado reiterativamente. 


\section{Derecho Comparado. Breve Referente de Evolución histórica del servicio público de televisión}

De acuerdo con antecedentes históricos frente al tema, el servicio público de televisión tuvo su origen primigenio en la necesidad de satisfacer la obtención de un mecanismo que fuera útil para reproducir imágenes; pero fue después de la primera guerra mundial que al contar con los tubos, invención de circuitos electrónicos y el desarrollo tecnológico de la trasmisión radiofónica, se generó un dispositivo para tal efecto; y una vez contando con el dispositivo útil se empezaron a generar realmente trasmisiones televisivas de carácter público, en condiciones básicas siendo pioneros en el tema la BBC de Londres, la CBS y NBC en Norte América; posteriormente hacia 1952 se conoce como antecedente del servicio público la operación del canal de televisión en España, de manera ya más evolucionada y adaptada con el desarrollo de las tecnologías. (Subgerencia Cultural del Banco de la República, 2015).

Posteriormente en Latinoamérica con impacto en México, por su grado de cubrimiento y proliferación de programas, espacios y canales de servicio público. País donde se cuenta con una organización e intervención gubernamental frente a la prestación del servicio público de televisión y el uso del espectro radioeléctrico, con competencias y funciones casi idénticas a las autoridades en Colombia, liderada por la Secretaria de Comunicaciones y Transporte, una comisión de Comunicaciones y con el Instituto Federal de Telecomunicaciones, este último realiza las funciones que en Colombia desarrolla y ejecuta la ANE, permaneciendo en cabeza de la Secretaria la facultad de adjudicar las concesiones del servicio de televisión y se encuentra plenamente concebida la libertad de tecnología, acceso a la información y libre competencia, siendo un país con operadores dominantes liderados por las programadoras Televisa, TV AZTECA, Telmex, pero con la competencia de un número importante de programadoras y operadores de televisión. La regulación ha ido de la mano con la Colombiana al ser países miembros de la UIT se guían por estándares homogéneos frente a políticas generales del sector de las Tic. Su regulación está concentrada en las Leyes Federales de Telecomunicaciones y de Radio y Televisión, siendo connotación común el hecho de que el uso del espectro radioeléctrico y el servicio público solo pueden ser prestados por concesionarios legitimados a través de procesos públicos de selección de contratista. (Biblioteca Juridica Virtual.Instituto de Investigaciones Jurídicas de la UNAM, 2011) ${ }^{58}$

En países de Latinoamérica como en el Perú la evolución del servicio ha transcurrido de lo precario y limitado en los derechos y principios que lo sustentaban, por las restricciones para su acceso y las finalidades mismas para las cuales se determinaba el servicio a un avance reglamentario que de acuerdo con lo analizado por el Doctor Samuel Abad Yupanqui en su artículo Derechos fundamentales y regulación de la radio y la televisión. La experiencia peruana, considera que en el Perú se ha tenido una deficiente evolución frente al manejo del servicio privado de interés público, mencionando como ejemplarizante el caso Colombiano en el que se da manejo constitucional al servicio y al espectro radioeléctrico que se usa para tal efecto. Expone que la Ley de Telecomunicaciones del Perú, no es completa ni cumple con las expectativas regulatorias que ha de concedérsele al tema, en cuanto no contiene la determinación de la naturaleza del servicio, la reglamentación de los contenidos y espacios obligatorios, se

58 Derechos Reservados, (C)2011 IIJ-UNAM. Instituto de Investigaciones Jurídicas de la UNAM- Circuito Maestro Mario de la Cueva s/n, Ciudad Universitaria, CP. 04510, México, D.F 
adolece de reglamentación detallada y clara en materia de concesiones; resaltando la necesidad de basar la prestación y la regulación en principios que abarquen todos los elementos integradores y sus fines. Y frente al tema de autoridades que intervengan en la administración y manejo del servicio y sus componentes considera textualmente: "lamentable que se haya desechado la idea de crear un Consejo de Radio y Televisión encargado de dar las autorizaciones, renovaciones e imponer las sanciones cuando se cometen infracciones., igualmente se hace referencia al hecho de que la regulación no está a la par de los avances en las tecnologías de la información, específicamente frente al servicio privado de interés público, connotación que limita aspectos como el pluralismo informativo, la competencia y la regulación de espacios. (2011)

En nuestro país, el desarrollo del servicio ha sido madurado de forma más evidente a partir de la primera selección de los operadores privados del servicio público con cubrimiento nacional en el año 1997, y además contando con la adjudicación de espacios de televisión; contando con antecedentes de evolución precaria desde el año 1954 época en la que el acceso al servicio dependía de la posibilidad de acceso a los recurso económicos para adquirir el dispositivo de alto costo y el servicio era brindado directamente por el Estado y en la medida en que surgían programadoras pequeñas con acceso a generar programas e importar otros empezaron a generarse espacios del servicio para estas programadoras; teniendo sus orígenes reales en 1954. De ahí a hoy luego del primer empuje transformador dado en 1997 no solo contamos con canales de manejo privado, sino que contamos con canales regionales, espacios concesionados y con manejo de todo tipo de contenidos, propendiendo por el ejercicio de la libertad de expresión, el derecho a la información y la necesidad de mantener a la comunidad informada de la realidad y acontecer nacional e internacional en los diferentes ámbitos. Y cuenta con un manejo regulatorio definido demarcado y en vigente aplicación.

A nivel europeo y norte americano, la regulación es dinámica, evolutiva de la mano con el desarrollo de las Tic y los derechos fundamentales de los ciudadanos, y su evolución se materializa en la mayoría de los reglamentos lidera en general las recomendaciones en la materia frente a la UIT; se cuenta con entes reguladores e intervencionistas claramente diferenciados que se fundamentan en el servicio de televisión como público.

\section{Conclusiones.}

De manera general se observa que en materia regulatoria Colombia es un país que ha venido evolucionando en una forma coherente con la evolución de las Tecnologías de la Información, y ello se ha reflejado en las disposiciones que hemos verificado a lo largo del primer componente y que se evidencian con mayor demarcación a partir del año 2009, la cual ha estado soportada en los planteamientos que se hacen sobre la materia en los planes y programas del Gobierno Nacional, que involucran no solo a un sector sino a todos, comprometidos en el avance tecnológico, la modernización de las operaciones, gestiones y trámites, usando tecnologías de vanguardia y de punta, aunado al hecho de contar con una estructura estatal intervencionista con funciones y límites de gestión claros enfocados a satisfacer el interés general.

En nuestro sentir, y ya frente al tema concreto objeto de análisis se verifica que el servicio público de televisión que se sirve del uso de las frecuencias del espectro radioeléctrico como componente del espectro electromagnético, para su prestación por parte de operadores privados, 
cuenta con un marco constitucional y legal claramente definido no solo en su alcance, sino en sus competencias, procedimientos, y particulares connotaciones como régimen especial que aunado a la aplicación del régimen general de contratación, propenden por la generación de procesos de carácter público, que presuponen la convocatoria pública, la pluralidad de interesados que en su desarrollo confluyan a que el Estado pueda concesionar el uso del Espectro y la Prestación del Servicio Público a quien le garantice no solo el uso eficiente de las correspondientes bandas, para los fines y propósitos establecidos, sino además que por ese derecho se obtenga un beneficio económico maximizado para el mismo Estado, lo que lleva implícito el deber de optimizar los recursos asignados y su correcto manejo dentro del marco de legalidad.

La reglamentación frente al licenciamiento, administración, intervención, planeación y uso del Espectro Electromagnético, se encuentra estrechamente ligada y aplicada en coherencia con las políticas de la Unión Internacional de Telecomunicaciones -UIT- de la cual forma parte Colombia, existiendo un organismo técnico encargado de su planeación y fijación de la disponibilidad de las bandas que quedaran afectadas a este uso, y nos referimos a la ANE, quien brinda la asesoría necesaria al Ministerio de Tic a efectos de poder generar los permisos y licencias que se requieren para tal efecto; con competencias claramente definidas, así como lo atinente a los requerimientos y procedimientos e instancias que deben agotarse, todas ellas tendientes a generar pluralidad de todo orden y libre competencia frente a su acceso.

La primera materialización en el Estado Colombiano, de otorgamiento de permisos de acceso al uso del espectro electromagnético orientado a la prestación del servicio público de televisión por parte de operadores privados y con cubrimiento nacional, se dio en el año 1997 celebrándose los correspondientes contratos de concesión con los operadores Caracol Televisión S.A., y RCN Televisión S.A, los cuales han sido objeto de prórroga, sin que haya sido posible la entrada de nuevos competidores al mercado de la prestación pese a los intentos del Gobierno, consagrados como propósitos en los Planes Nacionales de Desarrollo de las últimas administraciones nacionales y en las agendas estratégicas de las diferentes autoridades que intervienen en la administración del bien y servicio público, entiéndase Ministerio Tic, Fondo Tic, ANE, ANTV, $\mathrm{CRC}$, intentos que han contado con el acompañamiento de organismos de control, y han sido objeto de pronunciamiento por parte de la Corte Constitucional y del Consejo de Estado, en los que se evidencia la exigencia de generación de procesos que promuevan la libre competencia y el pluralismo, a través de la estructuración que de ellos haga el Estado como primer llamado a cumplir las disposiciones constitucionales y legales sobre la materia.

A la fecha en la que se está generando este análisis académico, se evidencia que las prórrogas de las concesiones estarían culminando aproximadamente en el año 2017, época para la cual no solo nos quedaríamos sin la operación de los actuales concesionarios dado que la Ley solo prevé la prórroga contractual por una sola vez, sino que no contamos con uno o más operadores nuevos que tengan adjudicada una concesión para poder iniciar su explotación comercial como prestatarios del servicio público de televisión, hecho que no solo ha de generar alarma para el Estado a través de los responsables de administrar el recurso escaso y el servicio público de televisión, sino para la comunidad en general, los organismos de control y todos aquellos agentes del estado llamados a garantizar el interés general.

Si bien es cierto Colombia cuenta con canales regionales, locales, espacios de televisión, y canales internacionales, estos no suplen ni reemplazan en sus finalidades la concepción de 
mantener operando canales privados de televisión con cubrimiento nacional, lo que potencialmente nos dejaría rezagados a nivel internacional en esta materia, y de ahí la necesidad no solo de generar con la mayor celeridad y diligencia un análisis que no solo viabilice sino que materialice el ingreso multiparticipativo de concesionarios a esa operación privada para cubrimiento nacional.

En el segundo componente de este trabajo académico nos dedicaremos a validar el procedimiento de selección de los operadores privados del servicio público con cubrimiento nacional, y los contratos, en aras de poder identificar si la regulación vigente limita o no de alguna manera el ejercicio de esa libre competencia como causa que haya impedido la entrada al mercado de nuevos competidores.

\section{REFERENCIAS BIBLIOGRAFICAS.}

Agencia Nacional de Contratación Pública. (25 de 10 de 2010). Detalle del Proceso Número CNTV-LP-002-2010. Adjudicación del Contrato de Concesión para la Operación y Explotación de un Tercer Canal de Televisión de Operación Privada de Cubrimiento Nacional, en las condiciones y términos que se determinan en el Pliego. (C. C. eficiente, Ed.) Bogotá, Colombia. Recuperado el 01 de Septiembre de 2015, de https://www.contratos.gov.co/consultas/detalleProceso.do?numConstancia=10-1-54504

Agencia Nacional de Contratación Pública. (16 de 09 de 2009). Detalle del Proceso Número CNTV-LP-001-2009 canal Tercer de tevisión. https://www.contratos.gov.co/consultas/detalleProceso.do?numConstancia=10-1-

54504, Bogotá, Colombia: Colombia Compra Eficiente SECOP. Recuperado el 20 de Septiembre de 2015, de http://www.contratos.gov.co/consultas/detalleProceso.do?numConstancia=09-1-42636

Agencia Nacional del Espectro -ANE-. (2013). http://www.ane.gov.co. Obtenido de http://www.ane.gov.co/index.php/component/jdownloads/finish/3/680.html?ltemid=0

Agencia Nacional del Espectro ANE. (22 de 09 de 2014). http://www.ane.gov.co. Recuperado el 24 de Septiembre de 2014, de http://www.ane.gov.co/index.php/conozca-la-ane/quees-el-espectro/que-es-el-espectro

Agencia Nacional del Espectro -ANE-. (22 de 09 de 2014). www.ane.gov.co. Recuperado el 26 de Septiembre de 2014, de www.ane.gov.co: http://www.ane.gov.co/cnabf/modulos/buscar_glosario_abc.php?letra=A\&id=16

Agencia Nacional del Espectro ANE. (26 de 09 de 2015). http://www.ane.gov.co. Recuperado el 05 de Octubre de 2014, de http://www.ane.gov.co: http://www.ane.gov.co/index.php/2011-11-21-02-37-29.html

Asamblea Nacional Constituyente. (1991). Constitución Política de colombia (Primera ed., Vol. 1). Bogotá.D.C, Colombia: Impre Andes S.A. Recuperado el 1 de Junio a Febrero de 20142015 
Atheortua Rios, C. A. (2006). Servicios Públicos Domiciliarios, Proveedores y Regimen de Controles. (primera ed., Vol. 1). Bogotá, Colombia: Universidad Externado de Colombia. Recuperado el 19 de febrero de 2015

Autoridad Nacional de Televisión. (2012). Respuestas a Comentarios del Sector a la Propuesta del Registro Unico de Operadores RUO del servicio de TV. Bogotá: Coordinación Normatividad Protección y Promoción.

Autoridad Nacional de Televisión ANTV. (12 de 12 de 2012). http://www.antv.gov.co/sites/default/files/121210_docrespuestas_ruo.pdf. Obtenido de Autoridad Nacional de Televisión: http://www.antv.gov.co/sites/default/files/121210_docrespuestas_ruo.pdf

Autoridad Nacional de Televisión. ANTV.Coordinación de Normatividad, Promoción y Protecccion. (12 de 12 de 2012). Agenda estrategica 2013. 1, 22. Bogotá, Colombia: Coordinación de Normatividad, Promoción y Protecccion. Recuperado el 26 de Junio de 2015, www.antv.gov.co/sites/default/files/121224_agendaestrategica_antv_2013.pdf

Autoridad Nacionalde Televisión. (03 de 12 de 2012). Agenda estrategica 2012 Autoridad Nacional de Televisión. 16. Bogotá, Colombia: Coordinacion de Regulacion y Normativa. Recuperado el 24 de Enero de 2015, de http://www.antv.gov.co/sites/default/files/resolucion_202_de_2012_ruo.pdf

Banca de inversión Equity Investment S.A. (2006). Informe de Consultoria . Bogotá: Contrato 062.

Banco de la República.Subgerencia Cultural. (2015). Los medios de comunicación audiovisual. Obtenido de www.banrep.gov.co: http://www.banrepcultural.org/blaavirtual/ayudadetareas/comunicacion/medios_audio visuales

Bernal Pulido, C. (Sf). www.externado.edu.co. Recuperado el 31 de Mayo de 2015, de EL JUICIO DE LA IGUALDAD EN LA JURISPRUDENCIA de la corte constitucional colombiana: http://portal.uexternado.edu.co/pdf/2_icrp/elJuicioDeLalgualdadEnLaJurisprudencia.pdf

Biblioteca Juridica Virtual.Instituto de Investigaciones Jurídicas de la UNAM. (01 de 01 de 2011). Derechos fundamentales y regulación de la radio y la televisión. La experiencia peruana. (S. B. Abad Yupanqui, Ed.) Lima, Perú. Recuperado el 20 de Abril de 2015, de /www.juridicas.unam.mx:

http://www.juridicas.unam.mx/publica/rev/decoin/cont/6/art/art1.htm.

Borrero Gonzalez, J. I., \& Bonilla, E. (2004). Regulación y Concesiones de la Televisión Colombiana:Destellos Y Sombras. Bogotá: Centro de Investigación para el Desarrollo CID- Universidad nacional.

Carrasquilla, A. (2008). "Precio de las Licencias de Televisión Abierta Para el Nuevo Período Regulatorio 2009-2018", . Bogota.

Carreño Rodriguez, C. B. (1995). El nuevo aire de la Televisión en Colombia: Entre la libertad y la Incertidumbre. Bogotá.: Facualtade de Comunicación y Lenguaje de la Pontificia Universidad Javeriana.

Castro Cuenca, C. G., Garcia López, L. F., \& Martinez Vargas, J. (2010). La Contratación Estatal.Teoria General.Perspectiva Comparada y Regulación Internacional (Primera ed., 
Vol. 1). Bogotá: Editorial Universidad del Rosario. Centro de Recursos de Apoyo al aprendizaje y a la Investigación. Recuperado el 1 de 12-06 de 2014-2015

Comisión de Regulación de Comunicaciones. (23 de 03 de 2012). Resumen Ejecutivo

"Diagnóstico del sector de televisión de Colombia y consulta pública para una agenda convergente". Bogota: CRC.

Congreso. (30 de 07 de 2009). Diario Oficial 47426 . Obtenido de http://www.alcaldiabogota.gov.co/sisjur/normas/Norma1.jsp?i=36913

Congreso. 109 de 06 de 2015). Obtenido de http://wp.presidencia.gov.co/sitios/normativa/Leyes/Documents/LEY\%201753\%20DEL\% 2009\%20DE\%20JUNIO\%20DE\%202015.pdf

Congreso de la República. (1887). Código Civil Colombiano. Ley 57 de 1887 Adopcion de Codigos y Unificación de Legislación Nacional (32a ed., Vol. 1). Bogotá., Colombia: LEGIS. Recuperado el 18 de febrero de 2015

Congreso de la Republica. (11 de 07 de 1994). Ley 142 de 1994. Régimen de los Servicios Públicos Domiciliarios. 1, 1, 597. Bogotá, Colombia: SEcretaria del Senado. Recuperado el 11 de marzo de 2015, de http://www.alcaldiabogota.gov.co/sisjur/normas/Norma1.jsp?i=2752

Congreso de la República. (20 de Enero de 1995). Ley 182 de 1995.Reglamenta el servicio de televisión y se formulan políticas para su prestación. 33. Bogotá, Colombia: Secretaria del Senado. Recuperado el 1 de junio de 2014, de www.mintic.gov.co: https://telecomunicacionescolombianormatividad.wordpress.com/Ley-182-de-1995/

Congreso de la República. (20 de 12 de 1996). Obtenido de www.mintic.gov.co: http://www.mintic.gov.co/portal/604/w3-article-3672.html

Congreso de la República. (20 de diciembre de 1996). Ley 335 de 1996. Se crea la prestacion del servicio público de televisión por parte de operadores privados, 33. Bogotá, Colombia. Recuperado el 5 de Junio de 2014, de http://www.alcaldiabogota.gov.co: http://www.alcaldiabogota.gov.co/sisjur/normas/Norma1.jsp?i=7155

Congreso de la República. (28 de 07 de 1999). www.secretariasenado.gov.co. Recuperado el 10 de Junio de 2014, de http://www.secretariasenado.gov.co.: http://www.secretariasenado.gov.co/senado/basedoc/Ley_0506_1999.html

Congreso de la República. (08 de 08 de 2001). Ley 680 de 2001. Disposiciones sobre inversion extranjera, metodologias de prestacion del servicio publico de televisión. 8. Bogotá, Colombia: Secretaria Senado. Recuperado el 14 de Junio de 2014, de www.mintic.gov.co: http://www.mintic.gov.co/portal/604/w3-article-3686.html

Congreso de la República. (16 de julio de 2007). Ley 1150 de 2007. Medidas de eficiencia y trnsparencia para aplicar el regimen legal determinado para la contratación con recursos publicos. Reforma al Estatuto General de contratación. 31. Bogotá, Colombia: Secretaría Senado. Recuperado el Julio 25 de 2014, de http://www.secretariasenado.gov.co/senado/basedoc/Ley_1150_2007.html

Congreso de la República. (30 de 07 de 2009). Ley 1341 de 2009. Régimen Legal del sector de Tecnologías de la Información y las Comunicaciones. 34. Bogotá., Colombia: Secretaria del Senado. Recuperado el 22 de Junio de 2014, de www.alcaldiabogota.gov.co: http://www.alcaldiabogota.gov.co/sisjur/normas/Norma1.jsp?i=36913 
Congreso de la República. (12 de 07 de 2011). Obtenido de www.esap.edu.co: http://hermesoft.esap.edu.co/esap/hermesoft/portal/home_1/rec/arc_12254.pdf

Congreso de la República. (12 de julio de 2011). Ley 1474 de 2011.Normas orientadas a fortalecerlos mecanismos de prevención, investigación y sanción de actos de corrupción y efectividad del control de la gestión pública. 77. Bogotá, Colombia: Secretaria Senado. Recuperado el 29 de Julio de 2014, de http://www.secretariasenado.gov.co/senado/basedoc/Ley_1474_2011.html

Congreso de la República. (10 de 01 de 2012). Ley 1507 de 2012. Regimen de intervencion del Estado y distribución de competencias frente al servicio de televisión. 11. Bogotá, Colombia: Secretaria del Senado. Recuperado el 5 de Julio de 2014, de www.antv.gov.co: http://www.antv.gov.co/nomatividad/Ley-1507-de-2012

Consejo de Estado. (20 de 11 de 2003). http://consejodeestado.gov.co. (Relatoria, Ed.) Recuperado el 15 de Octubre de 2014, de http://consejodeestado.gov.co/documentos/sentencias/47001233100020110000602.pd $f$

Consejo de Estado. (20 de 11 de 2003). www.cartagena.gov.co. Obtenido de http://www.cartagena.gov.co/Cartagena/secplaneacion/Documentos/pages/pot/files/n ormograma/Bienes_de_uso_publico_Arrendamiento_1.pdf

Consejo de Estado. (19 de 07 de 2001). Concepto Jurisprudencial Sobre la Licitacion Publica como Mecanismo de Selección de Contratista Radicación 11001-03-26-000. Bogotá, Colombia: Relatoria. Recuperado el 23 de Agosto de 2014, de http://www.alcaldiabogota.gov.co/sisjur/normas/Norma1.jsp?i=13311

Consejo de Estado. (5 de 10 de 2009). Adjudicación Tercer canal de Televisión. Inhabilidades para participar y mecanismos de asignación. Bogota, Colombia: Relatoria. Recuperado el 9 de Marzo de 2014, de http://webserver2.deloitte.com.co/Tax\%20\&\%20Legal/2012/legal/Sector\%20publico/7j unio/Consejo\%20de\%20Estado\%20-\%2016\%20de\%20febrero\%20de\%202012.pdf

Consejo de Estado. (14 de 02 de 2012). Recuperado el 20 de Marzo de 2015, de www.consejoestado.gov.co:

http://legal.legis.com.co/document/index?obra=jurcol\&document=jurcol_baa8bb24310 f0132e0430a0101510132

Coordinación de Normatividad, Protección y Promocion ANTV. (1 de 10 de 2012). Reglamentación del registro Unico de Operadores RUO del Servicio de Televisión. 1, 1, 44. Bogotá, Colombia. Recuperado el 26 de Diciembre de 2014, de www.antv.gov.co: http://www.antv.gov.co/sites/default/files/121003_docregulatorio_ruo.pdf

Coordinación de Regulación, Relaciones de Gobierno y Asesoría CRC. (01 de 07 de 2015). Simplificación Normativa para Promover la Competencia y la Inversión. Documento Final de Análisis. 1, 1, 23. Bogotá, Colombia: Coordinación de Regulación, Relaciones de Gobierno y Asesoría CRC. Recuperado el 2 de Noviembre de 2015, de www.crcom.gov.co/uploads

Corte Constitucional. (14 de julio de 2010). Concepto legal sobre la aplicacion del articulo 72 de la Ley 1341 de 2009. En cuanto se debe garantizar la pluralidad de interesados y la maximizacion de r3ecursos y otros demas inherentes al sevicio de television. 63. Bogotá, 
Colombia: Relatoria. Recuperado el 10 de 02 de 2015, de http://www.corteconstitucional.gov.co/relatoria/2010/c-570-10.htm

Corte Constitucional. (14 de 07 de 2010). www.corteconstitucional.gov.co. Recuperado el 24 de Noviembre de 2014, de http://www.corteconstitucional.gov.co/relatoria/2010/c-57010.htm

Corte Constitucional. (19 de 03 de 2014). Pronunciamiento sobre las normas de proteccion a la libre compentencia y libertad económica. 52. Bogotá, Colombia: Relatoria. Recuperado el 16 de marzo de 2015, de /www.corteconstitucional.gov.co: http://www.corteconstitucional.gov.co/relatoria/2014/C-172-14.htm

Corte Constitucional. (27 de 05 de 2010). Sentencia modulativa. Recuperado el 12 de febrero de 2015, de http://www.corteconstitucional.gov.co/relatoria/2010/C-403-10.htm

Corte Constitucional. (08 de 05 de 2013). Concepto sobre libertad economica y libre competencia. 45. Bogotá, Colombia. Recuperado el 22 de Marzo de 2015, de www.corteconstitucional.gov.co:

http://www.corteconstitucional.gov.co/relatoria/2013/c-263-13.htm

Dallos Jabbour, G. A. (2014). El ABC de la selección objetiva en la asignación del espectro radioelectrico con pluralidad de interesados. (Vol. 1). Bogotá, Colombia: Zetta Comunicaciones S.A. Procuraduría General de la Nación. Recuperado el 16 de Enero de 2015

Dávila Vinueza, L. G., \& Neyva Morales, A. I. (2015). Contratación Administrativa. Decreto1082 de 2015.Decreto de Unificación Régimen Reglamentario del Sector Administrativo de PLaneación Nacional (1 ed., Vol. 1). Bogotá, Colombia: Grupo Editorial Ibañez. Recuperado el 10 de Enero de 2015

Daza Duarte, S. P., \& Quinche Pinzón, R. H. (29 de 11 de 2012). Finalidad de los Principios y Valores Constitucionales en el contexto del Estado Social de Derecho en Colombia. 1, 1. Bogotá, Colombia. Recuperado el 15 de noviembre de 2014, de www.unilibre.edu.co: http://www.unilibre.edu.co/verbaiuris/images/stories/vol1/dc3.pdf

De la Quadra, T., Fernandez del Castillo, S., \& Vida Fernandéz, J. (2009). Derecho de la Regulación Económica.IV Telecomunicaciones (1 ed., Vol. IV). Madrid, España: IUSTEL. Fundación Instituto Universitario de Investigación Gustavo Ortega y Gaseset. Recuperado el 12 de Noviembre de 2014

Departamento Nacional de Planeación DNP. (09 de 06 de 2015). Bases Plan Nacional de Desarrollo 2014-2018. Todos por un Nuevo Pais. Ley 1753 de 2015. 793. Bogota, Colombia: DEpartamento Nacional de Planeación. Coordinación de Comunicaciones y Relaciones Públicas. Recuperado el 26 de Julio de 2015, de www.dnp.gov.co: https://colaboracion.dnp.gov.co/CDT/Prensa/Bases\%20Plan\%20Nacional\%20de\%20Des arrollo\%202014-2018.pdf

Departamento Nacional de Planeación-DNP. (2010). Bases del Plan Nacional de Desarrollo 20112014 Prosperidad para Todos. Más empleo,menos probreza y mas seguridad. y Ley 1450 de 2011. 1, 1, 861. (G. Celis Sarmiento, Ed.) Bogotá, D.C , Colombia, Colombia: Departamento Nacional de Planeación. Grupo Comunicaciones y Relaciones Públicas. Recuperado el 6 de Agosto de 2014, de https://colaboracion.dnp.gov.co/CDT/PND/Bases\%20PND\%2020102014\%20Versi\%C3\%B3n\%205\%2014-04-2011\%20completo.pdf 
Dromi, J. R. (1985). La licitación pública (Vol. 2a Edición). Buenos Aires, Argentina: Astrea.

El Espectador. (8 de 01 de 2010). Carlos Gustavo Arrieta explica la decisión de la CNTV. págs. http://www.elespectador.com/entretenimiento/arteygente/medios/audio-carlosgustavo-arrieta-explica-decision-de-cntv. Obtenido de http://www.elespectador.com/entretenimiento/arteygente/medios/audio-carlosgustavo-arrieta-explica-decision-de-cntv

Elink, P. (2002). Tratado de Defensa de la Libre Competencia. Legislación Doctrina y Jurisprudencia Regulatoria de la Libre Competencia. Lima: Fondo editorial de la Pontificia Universidad católica del Perú.

Fajardo Muriel, A. (2003). Nueva Realidad juridica de las Telecomunicaciones en Colombia. En: Lecciones en Materia de Telecomunicaciones (primera ed., Vol. 1). Bogotá, Colombia: Universidad Externado de Colombia. Recuperado el 25 de Marzo de 2015

González López, E. (2010). Comentarios a la Ley de Tecnologias de la Informacion y las Comunicaciones (primera ed., Vol. 1). Bogotá, Colombia: Universidad Externado de Colombia. Recuperado el 20 de Enero de 2015

Laso, E. S. (1940). La licitación Pública. (B. d. Sociales, Ed.) Montevideo, Uruguay.

Llaneza González, P. (2002). Nuevo Marco Regulatorio de las Telecomunicaciones (Primera ed.). Barcelona, España: BOSCH.

Madrid Aris, M. (2002). Terminos Técnicos de Telecomunicaciones. Miami Beach, FL: ICMAS Ltda. Public Utility Reaserch.

Ministerio de Tecnologías de la Información y las Comunicaciones. (12 de 04 de 2012). Obtenido de www.mintic.gov.co: http://www.mintic.gov.co/portal/604/w3-article-3546.html

Miranda Londoño, A. (1997). Abuso de la Posición Dominante.Perspectivas de la Aplicación en Colombia a la luz del Derecho Comparado (Vol. 1). Bogotá, Colombia: Centro de Estudios de Derecho de la Competencia. Recuperado el 12 de marzo de 2015

Miranda Londoño, A. (1 de 11 de 2003). El Derecho de la Competencia en el Servicio Público de Televisión. 1, 35. Bogotá, Colombia: Universidad Externado de Colombia. Recuperado el 24 de Noviembre de 2014, de www.uexternado.edu.co/derecho/pdf/derecho_telecomunicaciones/competencia:televi sion.pdf.

Moreno Molina, J. A. (2006). Los principios Generales de la Contratacion de las Administraciones Públicas (Vol. 1). Navarra, España: Bormazo Albacete. Recuperado el 26 de Octubre de 2014

Organizacion Internacional de Telecomunicaciones-ITU-. (12 de 02 de 2014). Portal de la UIT .Organismo especializado de las Naciones Unidas para las Tecnologías de la Información y la Comunicación - TIC. Ginebra, Suiza. Recuperado el 18 de febrero de 2015, de www.itu.int/es: http://www.itu.int/es/about/Pages/default.aspx

Paz Martinez, O. (2006). Reporte de Politicas TIC en Colombia. Asociación Colombiana de Organizaciones no gubernamentales para la comunicacion via correo electronico,Colnodo, Bogotá. Recuperado el 15 de Diciembre de 2014

Perez Luño, A. E. (2007). Dimensiones de la Igualdad (2a ed.). Madrid, España: Dykinson S L Melendez Valdez.

Perez Ramirez, B., \& Carrillo Benito, E. (2000). Desarrollo Local. Manual de Uso. Madrid, España: ESIC. 
Presidencia de la República. (10 de enero de 2012). Decreto Ley 0019 de 2012. Supresion o reforma de regulaciones, procedimientos y trámites innecesarios de la Administración Pública. 89. Bogota, Colombia: DEpartamento Administrativo de la Función Pública. Recuperado el 1 de Agosto de 2014, de www.funcionpublica.gov.co: https://www.funcionpublica.gov.co/normativa

Presidencia de la República. (30 de 12 de 1992). www.alcaldiabogota.gov.co. Recuperado el 15 de Diciembre de 2014, de www.alcaldiabogota.gov.co: http://www.alcaldiabogota.gov.co/sisjur/normas/Norma1.jsp?i=38168

Presidencia de la República. (19 de 01 de 2010). www.alcaldiabogota.gov.co. Recuperado el 02 de 12 de 2014, de www.alcaldiabogota.gov.co: http://www.alcaldiabogota.gov.co/sisjur/normas/Norma1.jsp?i=38669

Ramirez Ramirez, A. (01 de 09 de 2001). Una Peligrosa Posición Dominante.

Revista Semana. (06 de 12 de 2008). No quiero quebrar ni a RCN ni a Caracol. No quiero quebrar ni a RCN ni a Caracol. Recuperado el 29 de 11 de 2014, de http://www.semana.com/economia/articulo/canales-privados-firman-prorroga/98959-3

Santofimio, J. O. (2010). El Contrato de Concesión de Servicios Públicos. Coherencia con los Postulados del EStado Social y Democrático de Derecho en aras de su Estructuración en Función del Interes Publico(Tesis Doctoral). Bogotá: Gatafe.

Subgerencia Cultural del Banco de la República. (01 de 01 de 2015). Los medios de comunicación audiovisual. Fondo Abierto de Autores Colombianos. (F. a. Greiff, Ed.) Bogotá., Colombia: http://www.banrepcultural.org/blaavirtual/ayudadetareas/comunicacion/medios_audio visuales. Recuperado el 26 de abril de 2015, de www.banrep.gov.co: http://www.banrepcultural.org/blaavirtual/ayudadetareas/comunicacion/medios_audio visuales

Superintendencia de Industria y Comercio. (sf de sf de 2010). Obtenido de http://www.sic.gov.co/recursos_user/documentos/articulos/2010/Guia_Contratacion.p df

Tapias Perdigon, C. (2000). Aspectos Prácticos de la Contratación Pública. Ley 80 de 1993 explicada y comentada.Solución a inquietudes frecuentes. (1 ed., Vol. 1). Bogotá., Colombia.: Casa Editorial Grupo Ecomedios. Recuperado el 18 de Julio de 2014

Union Internacion de Telecomunicaciones UIT. (01 de 06 de 2014). https://academy.itu.int/index. Recuperado el 16 de Noviembre de 2014, de https://academy.itu.int/index.:

https://academy.itu.int/index.php?option=com_joomdle\&view=coursecategoryextende d\&cat_id=:\&course_id=764:metodos-de-atribucion-y-asignacion-delespectro\&ltemid=476\&lang=en

Union Internacional de Telecomunicaciones UIT. (26 de 10 de 2013). www.ane.gov.co. Recuperado el 27 de Septiembre de 2014, de www.ane.gov.co: http://www.ane.gov.co/index.php/component/jdownloads/finish/3/680.html?ltemid=0

Unión Internacional de Telecomunicaciones UIT. (s.f.). Manual Comprobación Técnica del Espectro. (F. Rancy, Ed.) Ginebra, Suiza: Oficina de Radio Comunicaciones. Division ventas y Comercialización. Recuperado el 14 de Abril de 2015, de www.itu.int.es: http://www.itu.int/es/about/Pages/overview.aspx 
Unión Internacional de Telecomunicaciones-UIT-. (01 de 12 de 2011). www.ane.gov.co. Recuperado el 24 de Septiembre de 2014, de www.ane.gov.co: http://www.ane.gov.co/index.php/conozca-la-ane/que-es-el-espectro/que-es-elespectro

Unión Temporal Correval-CGI, . (2008). Modelo de valoracion y analisis de riesgos. Bogotá: Contrato 052.

Unión Temporal Valoración Concesión TV Abierta . (2008). Modelo Base de valoración y recomendación en materia de tipificacion y asignacion de riesgos. Bogota: Contrato 035.

Universidad de Alcala.

(s.f.). http://www3.uah.es/bibliotecaformacion/BPOL/FUENTESDEINFORMACION. Recuperado el 26 de noviembre de 2015, de Biblioteca Universidad de Alcala: http://www3.uah.es/bibliotecaformacion/BPOL/FUENTESDEINFORMACION/normas_tcni cas.html 